\title{
Spring-summer imbalance of dissolved inorganic carbon in the mixed layer of the northwestern Sargasso Sea
}

\author{
By OLIVIER MARCHAL ${ }^{1 *}$, PATRICK MONFRAY ${ }^{1}$ and NICHOLAS R. BATES ${ }^{2}$, ${ }^{1}$ Centre des \\ Faibles Radioactivités, Laboratoire mixte CNRS-CEA, 91198 Gif-Sur-Yvette Cedex, France; ${ }^{2}$ Bermuda \\ Biological Station for Research, Ferry Reach, GE-01, Bermuda
}

(Manuscript received 10 February 1994; in final form 1 August 1995)

\begin{abstract}
The surface concentration of dissolved inorganic carbon (DIC) at the Bermuda Atlantic Timeseries Study site (BATS) decreased gradually by ca. $30 \mu \mathrm{mol} \mathrm{kg}^{-1}$ from April to October in 1989 . This decrease occurred almost in the absence of measurable nitrate in the mixed layer. Although ancillary data about the $\mathrm{C}$ system point to the possible importance of lateral transport, horizontal gradients in surface [DIC] and the mean flow in the area indicate that local effects should prevail in the seasonal drawdown of DIC. On the basis of an one-dimensional model, we hence estimate the mixed layer budget of DIC for this period, from surface [DIC] data, temperature profiles, and concomitant meteorological records. According to model uncertainties, the [DIC] drawdown should be mostly explained $(71-93 \%)$ by a net community production (NCP) averaging 1.4-2.3 $\mathrm{mgC} \mathrm{m}^{-3} \mathrm{~d}^{-1}$, and to a lesser extent, by outgassing of $\mathrm{CO}_{2}$ to the atmosphere. These losses are partially compensated $(<30 \%)$ by mixing with DIC-rich waters of the thermocline. This NCP must be regarded as a lower estimate, since the mean flow from the northeast should bring waters with slightly higher [DIC] to the mixed layer at the BATS site. The model, which is sensitive to short-term variations in atmospheric forcing $(<1$ day), indicates that this layer has never reached the nitrocline for spring-summer 1989, even as a hurricane passed through the region. Hence, the surface NCP should not have been supported by unsampled, pulse-like supplies of deep nutrients. Wet atmospheric deposition of nitrogen measured concurrently on Bermuda could contribute to the biological N requirement $(10-20 \%)$. According to historical estimates, $\mathrm{N}_{2}$ fixation seems however insufficient to meet the remaining demand. Comparison between NCP and primary production measured in situ suggests that most of photosynthetically fixed $\mathrm{C}(>50 \%)$ is not respired in the mixed layer.
\end{abstract}

\section{Introduction}

In the northwestern Sargasso Sea, the concentration of dissolved inorganic carbon (DIC) and alkalinity are measured regularly, at the US JGOFS Bermuda Atlantic Time-series Study site (BATS: $31^{\circ} 50^{\prime} \mathrm{N}, 64^{\circ} 10^{\prime} \mathrm{W}$; see Bates et al., $1992,1993,1994)$ and at station $\mathrm{S}\left(32^{\circ} 10^{\prime} \mathrm{N}\right.$, $64^{\circ} 30^{\prime} \mathrm{W}$; see Keeling (1993)). According to surface measurements, [DIC] decreases each year gradually for spring-summer after the onset of stratification (typically by $30-40 \mu \mathrm{mol} \mathrm{kg}{ }^{-1}$ ). By contrast, the alkalinity remains generally a well-

\footnotetext{
* Corresponding author.
}

defined function of salinity (Bates et al., 1992, 1993; Keeling, 1993). These observations, and the concomitant enrichment of surface DIC in ${ }^{13} \mathrm{C}$ at station S (Keeling, 1993), point to net community production of organic carbon (gross primary production minus community respiration) as an important process in the mixed layer near Bermuda (ML). Yet the [DIC] drawdown occurs almost in the absence of measurable nitrate and phosphate in this region of the subtropical gyre (Menzel and Ryther, 1960; Michaels et al., 1994a). Thus, this drawdown was first suggested to reflect a biological activity which, as a whole, departs from the standard Redfield stoichiometry (Keeling, 1993; Toggweiler, 1993). 
However, the lateral transport of low-DIC waters was more recently called for to explain the fact that the seasonal drop of carbon stocks in the $0-150 \mathrm{~m}$ stratum near the BATS site, is much higher (3-fold) than the sum of vertical fluxes of $C$ out of this stratum (provided that the export of sinking particles is accurately measured with traps; Michaels et al., 1994b). Yet, the mean flow near Bermuda is mainly from the northeast as part of the Gulf Stream recirculation (Worthington, 1976), and seasonal north-south transects show higher surface [DIC] north off Bermuda (Bates, 1995; Bates et al., 1995). This flow should transport DIC-rich waters into the mixed layer south off Bermuda where sampling sites are located. Thus, lateral advection should in fact reinforce the vertical $\mathrm{C}$ imbalance noticed above (instead of explaining part of it, see Toggweiler (1995)). An upper value of this effect can be roughly estimated from the amplitude of the recirculation flux $\left(<3-4 \mathrm{~cm} \mathrm{~s}^{-1}\right.$, see Olbers et al. (1985)) and from seasonal meridional gradients in surface [DIC] $\left(<12 \mu \mathrm{mol} \mathrm{kg}{ }^{-1}\right.$ over a distance of $600 \mathrm{~km}$, see Bates (1995)). The mean flow should hence contribute to a maximum of ca. $30 \%$ of the local drawdown. This contribution is likely to be lower. Eddies could on the other hand also affect the $\mathrm{C}$ budget in the mixed layer. However, although eddies are apparent in the time series of salinity at the BATS site, [DIC] variations are not strongly related to salinity changes (Michaels et al., 1994b). Moreover, the possible implication of eddies is poorly compatible with the fact that the [DIC] drawdown near Bermuda occurs each year gradually on a timescale of several months. Thus, local effects probably dominate over net lateral avection in the seasonal drawdown of surface DIC at the BATS site (Michaels et al., 1994b).

In this study, we hence determine, by assuming a vertical balance, the ML net community production (NCP) from the surface [DIC] drawdown which occurred at the BATS site from April to October in 1989. This NCP should be considered as a lower estimate, since the transport of waters with slightly higher [DIC] from the north would tend to decrease the amplitude of the drawdown. The relative impact of gas exchange and vertical mixing from the seasonal thermocline on the ML budget of DIC, is assessed using a diagnostic model constrained by monthly oceanic sampling and short-time variations $(<1$ day) in meteoro- logical forcing. We then consider whether the nitrogen requirement for the photosynthetic production could be supported by unsampled, transient supplies of nutrients from deep water. This $\mathrm{N}$-demand is further compared to concomitant measurements of wet $\mathrm{N}$ deposition on Bermuda and to previous estimates of $\mathrm{N}_{2}$ fixation. The required community production is finally compared to concurrent measurements of primary production in the ML at the BATS site.

\section{Method}

\subsection{Data}

Measurements of meteorological parameters on Bermuda and of hydrography and chemical/ biological properties at the BATS site have been previously published in BATS data reports (Knap et al., 1991, 1992) and elsewhere (Lohrenz et al., 1992; Michaels et al., 1994a). In this study, we use daily meteorological data and monthly oceanic measurements of discrete properties, such as temperature, salinity, $\left[\mathrm{O}_{2}\right]$, and [DIC]. Sampling and analytical protocols are given in the BATS method manual (Knap et al., 1993). Measurements of [DIC] was made at the Woods Hole Institution of Oceanography using a high precision $\left( \pm 2 \mu \mathrm{mol} \mathrm{kg}^{-1}\right.$ ) coulometric technique described by Goyet and Hacker (1992).

The evolution of sea surface temperature (SST) and temperature profiles from April to October 1989 are shown in Figs. 1 and $2 \mathrm{~A}-\mathrm{G}$, respectively. The SST increased by ca. $6^{\circ} \mathrm{C}$ from April to July. The ML shoaled from 35-55 $\mathrm{m}$ in April to $15-25 \mathrm{~m}$ in June-July. A transient cooling of the ML by about $1{ }^{\circ} \mathrm{C}$ was observed in early August, probably associated with the passage of hurricane Dean through the region (Roman et al., 1993; Malone et al., 1993). Thereafter, the SST has increased. After September, the ML cooled and deepened progressively during autumn and winter.

The seasonal evolution of mixed layer [DIC] at the BATS site and station S is shown in Fig. 3 for the 1989-1990 period. [DIC] values have been normalized to a mean surface salinity of 36.6 in order to remove the effect of evaporation/ precipitation on the water mass balance. At the BATS site, [DIC] decreased gradually by ca. $30 \mu \mathrm{mol} \mathrm{kg}^{-1}$ from May to October in 1989. This 
decrease is similar to that observed at the same time in subsequent years (see Bates et al., 1993) and at station $\mathrm{S}$ for the previous years (Keeling, 1993). During autumn, the mixed layer [DIC] gradually increased, reaching a maximum in winter (Bates et al., 1992, 1993; Keeling, 1993).

\subsection{Diagnostic model of the DIC budget in the mixed layer}

In order to explain the surface [DIC] drawdown at the BATS site, meteorological and oceanic data for spring-summer 1989 were merged into a diagnostic model. In this model, the continuity equation for DIC $\left(\mathrm{mgC} \mathrm{m}^{-3}\right)$ is expressed as:

$$
\frac{\partial[\mathrm{DIC}]}{\partial t}=\frac{\partial F}{\partial z}-\phi
$$

where $F\left(\mathrm{mgC} \mathrm{m}^{-2} \mathrm{~d}^{-1}\right)$ is the vertical flux of DIC and $\phi\left(\mathrm{mgC} \mathrm{m}^{-3} \mathrm{~d}^{-1}\right)$ refers to the net biological exchange (following the terminology of Keeling, 1993). In the water column, the flux $F$ is related to eddy diffusion:

$F=k \frac{\partial[\mathrm{DIC}]}{\partial z}$,

where $k$ is the vertical eddy diffusivity $\left(\mathrm{m}^{2} \mathrm{~d}^{-1}\right)$. The budget equation of DIC in the ML is derived by integrating eq. (1) between the surface (referenced by 0 ) to the base of the ML (referenced by $z_{\mathrm{ML}}$ ). For that purpose, the Leibnitz rule is used for the left-hand side derivative:

$$
\begin{aligned}
& \int_{0}^{z_{\mathrm{ML}}} \frac{\partial[\mathrm{DIC}]}{\partial t} \mathrm{~d} z=\frac{\mathrm{d}}{\mathrm{d} t} \int_{0}^{z_{\mathrm{ML}}}[\mathrm{DIC}] \mathrm{d} z \\
& \quad-[\mathrm{DIC}]_{z_{\mathrm{ML}}} \frac{\mathrm{d} z_{\mathrm{ML}}}{\mathrm{d} t}=F_{z_{\mathrm{ML}}}-F_{0}-\int_{0}^{z_{\mathrm{ML}}} \phi \mathrm{d} z,
\end{aligned}
$$

where $F_{z \mathrm{ML}}$ is the upward flux of DIC via eddy diffusion through the base of the ML (where $[\mathrm{DIC}]=[\mathrm{DIC}]_{z_{\mathrm{ML}}}$ ) and $F_{0}$ is the net sea-to-air flux of $\mathrm{CO}_{2}$. The mean concentration of DIC in the ML is defined as

$$
\langle[\mathrm{DIC}]\rangle=\frac{1}{z_{\mathrm{ML}}} \int_{0}^{z_{\mathrm{ML}}}[\mathrm{DIC}] \mathrm{d} z
$$

Its continuity equation is thus:

$$
\frac{\mathrm{d}\langle[\mathrm{DIC}]\rangle}{\mathrm{d} t}=F_{\mathrm{TOT}}^{*}=F_{\mathrm{UT}}^{*}-F_{0}^{*}-F_{\mathrm{BIO}}^{*}
$$

where

$$
F_{\mathrm{UT}}^{*}=\frac{F_{z_{\mathrm{ML}}}}{z_{\mathrm{ML}}}+\frac{1}{z_{\mathrm{ML}}} \frac{\mathrm{d} z_{\mathrm{ML}}}{\mathrm{d} t}\left([\mathrm{DIC}]_{z_{\mathrm{ML}}}-\langle[\mathrm{DIC}]\rangle\right),
$$

$F_{0}^{*}=\frac{F_{0}}{z_{\mathrm{ML}}}$

$F_{\mathrm{BIO}}^{*}=\frac{1}{z_{\mathrm{ML}}} \int_{0}^{z_{\mathrm{ML}}} \phi \mathrm{d} z$.

Here, $F_{\mathrm{UT}}^{*}, F_{0}^{*}$, and $F_{\mathrm{BIO}}^{*}\left(\mathrm{mgC} \mathrm{m}^{-3} \mathrm{~d}^{-1}\right)$ are the $\langle[\mathrm{DIC}]\rangle$ variations per unit time associated respectively with mixing at the base of the ML, the air-sea flux of $\mathrm{CO}_{2}$, and the net biological exchange (the asterisk indicates that these fluxes are expressed per unit of water volume). The last term on the right-hand side of eq. (5a) simply states that the mean concentration [DIC] also varies if water layers incorporated into the $\mathrm{ML}$ during deepening $\left(\mathrm{d} z_{\mathrm{ML}} / \mathrm{d} t>0\right)$, or released during shoaling $\left(\mathrm{d} z_{\mathrm{ML}} / \mathrm{d} t<0\right)$, have a different concentration than $\langle[D I C]\rangle$. In this study, each flux in eq. (5) is calculated diagnostically. To this end, the continuity eq. (1) is solved according to the procedures described below.

2.2.1. Vertical mixing. In order to estimate the vertical profile $k(z)$ between sampling dates $(\approx 1$ month), the one-dimensional physical model of Gaspar et al. (1990) is used and driven at the surface by heat fluxes and wind stresses. The eddy diffusivity is fully constrained in this way by a turbulent closure scheme, so that $k$ is not a free parameter in our study (see Musgrave et al., 1988). Here, eq. (1) and conservation equations for temperature, horizontal velocity, and turbulent kinetic energy (TKE) are solved on a 300 -m-thick vertical grid, with a depth increment $\Delta z=5 \mathrm{~m}$ and a time step $\Delta t=15 \mathrm{~min}$ (Appendix A). Heat fluxes and wind stresses are calculated using bulk formulae from meteorological parameters recorded on Bermuda (Appendix B). This meteorological record (Figs. 4) is concomitant with the sampling period at sea and comprises at least one observation per day for each parameter for the AprilOctober period in 1989. On the other hand, there is no exchange of heat and energy through the lower boundary of the model domain (at $300 \mathrm{~m}$ ), 
i.e., vertical gradients at this level are neglected (Gaspar et al., 1990). To start the simulation, the temperature profile measured in April (Fig. 2A) is linearly interpolated on the model grid. On the other hand, in the absence of adequate measurements, a condition of no motion is prescribed initially throughout the water column, and TKE is set equal to $10^{-4} \mathrm{~m}^{2} \mathrm{~s}^{-2}$ in the $\mathrm{ML}$ and to $10^{-6} \mathrm{~m}^{2} \mathrm{~s}^{-2}$ below the ML, as in Gaspar et al. (1990) (see Appendix A). The depth of the ML is determined using a $\Delta T=0.5^{\circ} \mathrm{C}$ criterion, as applied for station S by Spitzer and Jenkins (1989). The other necessary specifications about the physical model are given in Appendix A. Details of the turbulent closure scheme can be found in Bougeault and Lacarrère (1989), Gaspar et al. (1990), and Blanke and Delécluse (1993).

The physical model is able to reproduce the evolution of the SST with a RMS error of $0.3^{\circ} \mathrm{C}$ for the April-October period $(n=6)$ and a maximum error of $0.5^{\circ} \mathrm{C}$ in August (Fig. 1). In early August, high winds and low temperatures were recorded on Bermuda as hurricane Dean passed through the region (Figs. 4A, C, respectively). In the simulation, this meteorological forcing triggers mixing with cold thermocline waters and a sudden decrease in SST (ca. $1.5^{\circ} \mathrm{C}$ ). This leads to an evolution in agreement with the data (Fig. 1).

Although the simulation of the SST is quite realistic from April to October, the thermal gradients that it develops progressively at the base of the $\mathrm{ML}$ are too sharp in comparison with observed temperature profiles (Figs. 2D-F). Application of the same model in the northeast Pacific also resulted in an underestimate of mixing in the upper thermocline during summer-early autumn (Gaspar et al., 1990; Thomas et al., 1993). Thus, if subsurface values of $k$ produced in this way are used in the diagnostic model, the exchange of DIC between the ML and the upper thermocline may also be underestimated (eqs. (1) and (5)).

We have hence modified the eddy diffusivities in the upper thermocline using the following procedure. It is noticed that in the turbulent closure scheme, $k$ depends on the local density stratification, and hence on the local thermal gradient (the lower this gradient, the larger the $k$ value) (Gaspar et al., 1990). Therefore, eddy diffusivities should be corrected if temperature profiles produced by the model compare favourably to the observations. Thus, these profiles are altered by introducing a correction flux $H_{\mathrm{T}}\left({ }^{\circ} \mathrm{C} \mathrm{d}^{-1}\right)$ into the heat equation of the model:

$$
\left(\frac{\partial T}{\partial t}\right)_{\mathrm{C}}=\left(\frac{\partial T}{\partial t}\right)_{\mathrm{U}}+H_{\mathrm{T}}
$$

The symbols ( $)_{C}$ and ()$_{U}$ refer to heating rates that are constrained and unconstrained by the heat flux $H_{\mathrm{T}}$, respectively. A profile $H_{\mathrm{T}}(z)$ is calculated for each time interval between 2 sampling dates (noted $t_{i}$ below), so that temperature profiles

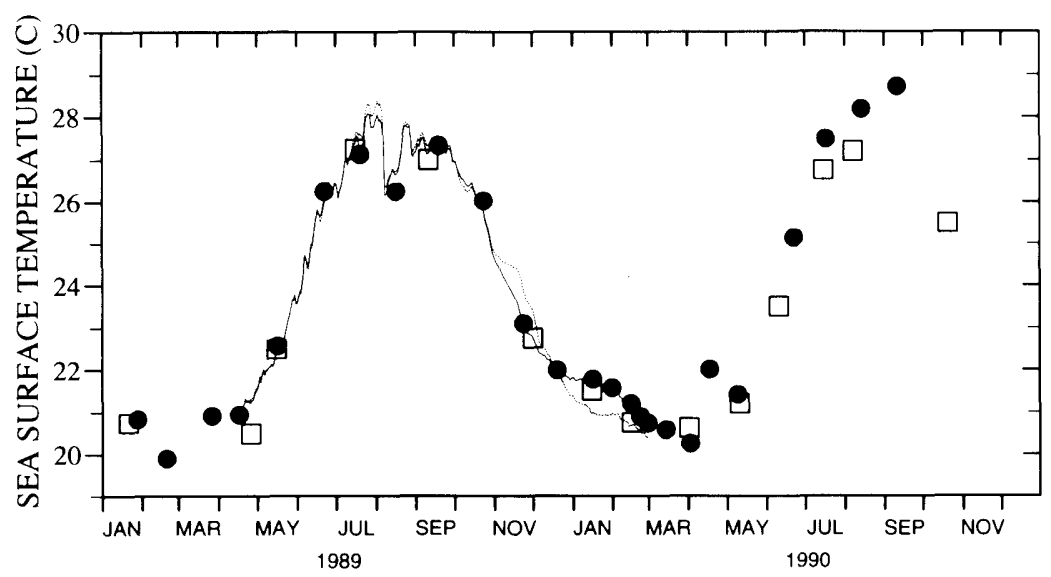

Fig. 1. Sea surface temperature in the northwestern Sargasso Sea for 1989-1990. Circles represent data at the BATS site $\left(31^{\circ} 50^{\prime} \mathrm{N}, 64^{\circ} 10^{\prime} \mathrm{W}\right)$ from Knap et al. $(1991,1992)$ and squares are data at station $\mathrm{S}\left(32^{\circ} 10^{\prime} \mathrm{N}, 64^{\circ} 30^{\prime} \mathrm{W}\right)$ extracted from Fig. 1 in Keeling (1993). The dashed line is the result of the physical model. The solid line is the result of this model when corrected by temperature profiles measured in situ (see text). 


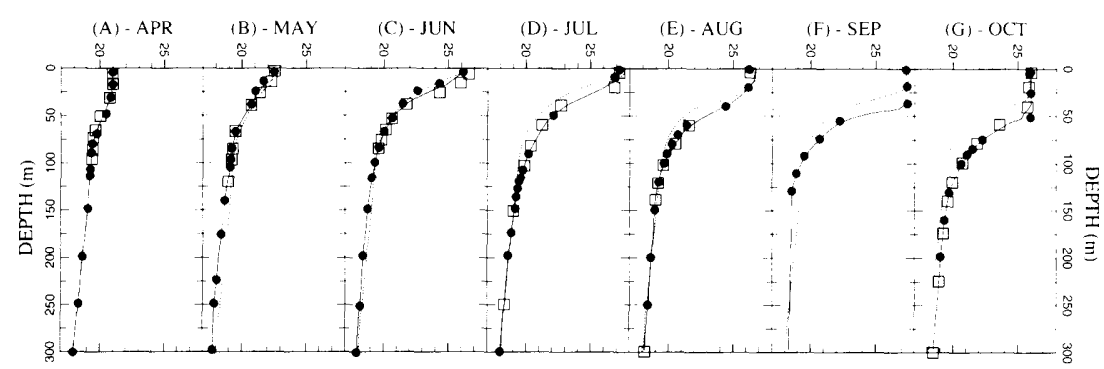

Fig. 2. Vertical profiles of temperature $\left({ }^{\circ} \mathrm{C}\right)$ in the upper water column at the BATS site from April to October 1989. Circles and squares represent different bottle casts for the same cruise (data from Knap et al., 1991, 1992). The dashed line is the result of the physical model. The solid line is the result of this model when corrected by temperature profiles measured in situ (see text).

calculated by the model match, in the least squares sense, that measured in situ at the end of $t_{i}$. For that purpose, conservation equations of the physical model are solved repeatedly for this interval in order to progressively constrain $H_{\mathrm{T}}(z)$ (the correction flux is derived by comparing, at the end of $t_{i}$, the temperature profile produced by the model to that measured). This iterative procedure stops once the RMS error of model temperatures at sampling depths in the top $300 \mathrm{~m}$ is less than $0.1^{\circ} \mathrm{C}$. Convergence is rapidly reached $(\approx 1$ iteration) since the correction flux is mostly important in the upper thermocline where calories introduced via $H_{\mathrm{T}}$ are essentially stored locally. It is seen that this procedure corrects the thermal gradients simulated in the thermocline (Figs. 2D-F). On the other hand, it introduces only a minimal effect on the model SST from April to October (Fig. 1).

2.2.2. Air-sea exchange of $\mathrm{CO}_{2}$. The integration of continuity eq. (1) requires boundary conditions at the sea surface and at $300 \mathrm{~m}$. In our model, DIC does not diffuse through the bottom boundary, assuming that the vertical gradient in [DIC] is nil at this level. [DIC] profiles measured at the

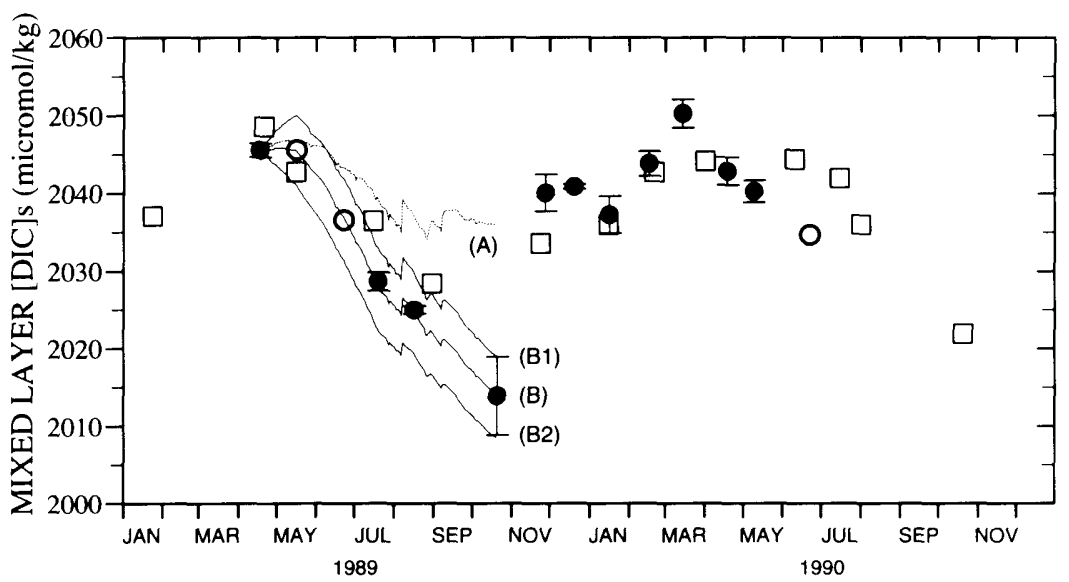

Fig. 3. Concentration of dissolved inorganic carbon (DIC) in the mixed layer of the northwestern Sargasso Sea for 1989-1990. All values are normalized to the mean surface salinity of 36.6 (i.e. [DIC] $=$ [DIC] $36.6 / S$, where $S$ is salinity). Circles represent mean values for water samples collected in the mixed layer at the BATS station and horizontal bars indicate one standard deviation around these values (an open circle is reported when only one measurement is available) (data from Knap et al., 1991, 1992). Squares are surface data at station S extracted from Fig. 1 in Keeling (1993). The 3 solid lines are results of the diagnostic model: (1) line (A) is when the biological uptake of carbon is not accounted for; (2) line (B) is the result of the standard version of the diagnostic model; (3) lines (B1) and (B2) are produced by this model when [DIC] data are increased and decreased by $5 \mu \mathrm{mol} \mathrm{kg}^{-1}$, respectively. The depth of the mixed layer is determined using a $\Delta T=0.5^{\circ} \mathrm{C}$ criterion (see text). 
BATS site (Knap et al., 1991) and at nearby stations sampled as part of the Transient Tracers in the Ocean study (TTO, 1986), reveal that [DIC] gradients are indeed low near $300 \mathrm{~m}$ (not shown). Moreover, the prescription of a no-flux condition at this level shoud have insignificant effect on our results, since the base of the ML remains much shallower than $300 \mathrm{~m}$ from April to October (Figs. $2 \mathrm{~A}-\mathrm{G}$ and 9).

At the surface, the rate of gas exchange from sea to air is calculated from:

$F_{0}=v_{\mathrm{p}} \alpha\left(\mathrm{pCO}_{2}^{\mathrm{w}}-\mathrm{pCO}_{2}^{\mathrm{a}}\right)$,

where $v_{\mathrm{P}}\left(\mathrm{m} \mathrm{s}^{-1}\right)$ is the piston velocity for $\mathrm{CO}_{2}$ through the surface, $\alpha\left(\mathrm{mgC} \mathrm{m}^{-3} \mu \mathrm{atm}^{-1}\right)$ is the Henry solubility coefficient for $\mathrm{CO}_{2}$ in seawater, and $\mathrm{pCO}_{2}^{\mathrm{w}}$ and $\mathrm{pCO}_{2}^{\mathrm{a}}$ (both in $\mu \mathrm{atm}$ ) are the partial pressures in the surface water and in air, respectively. The calculation of the gas exchange is detailed in Appendix B. Briefly, $v_{\mathrm{P}}$ is derived from 4-h mean wind speeds recorded on Bermuda simultaneously with the sampling period at the BATS site, while $\alpha$ is modulated by SST variation. $\mathrm{pCO}_{2}^{\mathrm{w}}$ is computed from the SST and surface [DIC] assuming constant salinity and alkalinity, and $\mathrm{pCO}_{2}^{\mathrm{a}}$ is inferred from an atmospheric $\mathrm{CO}_{2}$ record on Bermuda for 1989. As alkalinity is taken constant, the biological exchange in eqs. (1) and (5) is equivalent to net community production of organic carbon.

2.2.3. Net community production. Following previous diagnostic studies (Musgrave et al., 1988; Thomas et al., 1990, 1993; Garçon et al., 1992), net community production is formulated according to a simple profile (see below). Using the model, NCP in the ML $\left(\phi_{0}\right)$ is estimated from ML measurements of [DIC]. For that purpose, the continuity eq. (1) is repeatedly solved between 2 sampling dates, until the mean ML [DIC] calculated by the model, $\langle[\mathrm{DIC}]\rangle_{\mathrm{c}}$, matches that measured in situ, $\langle[D I C]\rangle_{\circ}$ (the initial condition for this equation is the [DIC] profile of April 1989, see Fig. 6A, linearly interpolated on the model grid). During each time interval $t_{i}$, this equation is solved with $k$ provided by the physical model and corrected by temperature profiles, and with the rate of $\mathrm{CO}_{2}$ exchange as the boundary condition at the surface. NCP in the ML is increased during the course of these iterations, until the following equality is satisfied:

$$
\begin{aligned}
& \int_{t}^{t+t_{i}} \frac{\mathrm{d}\langle[\mathrm{DIC}]\rangle_{\mathrm{c}}}{\mathrm{d} t} \mathrm{~d} t \\
& \quad=\int_{t}^{t+t_{i}} \frac{\mathrm{d}\langle[\mathrm{DIC}]\rangle_{\mathrm{o}}}{\mathrm{d} t} \mathrm{~d} t+a_{1}
\end{aligned}
$$

where $a_{1}$ is the allowance in the iterative scheme $\left(a_{1}=1 \mu \mathrm{mol} \mathrm{kg}^{-1}\right.$, on the basis of the mean of standard deviations of [DIC] replicates in the $\mathrm{ML})$. Convergence is also reached rapidly $(\approx 1$ iteration) since carbon introduced in the ML via

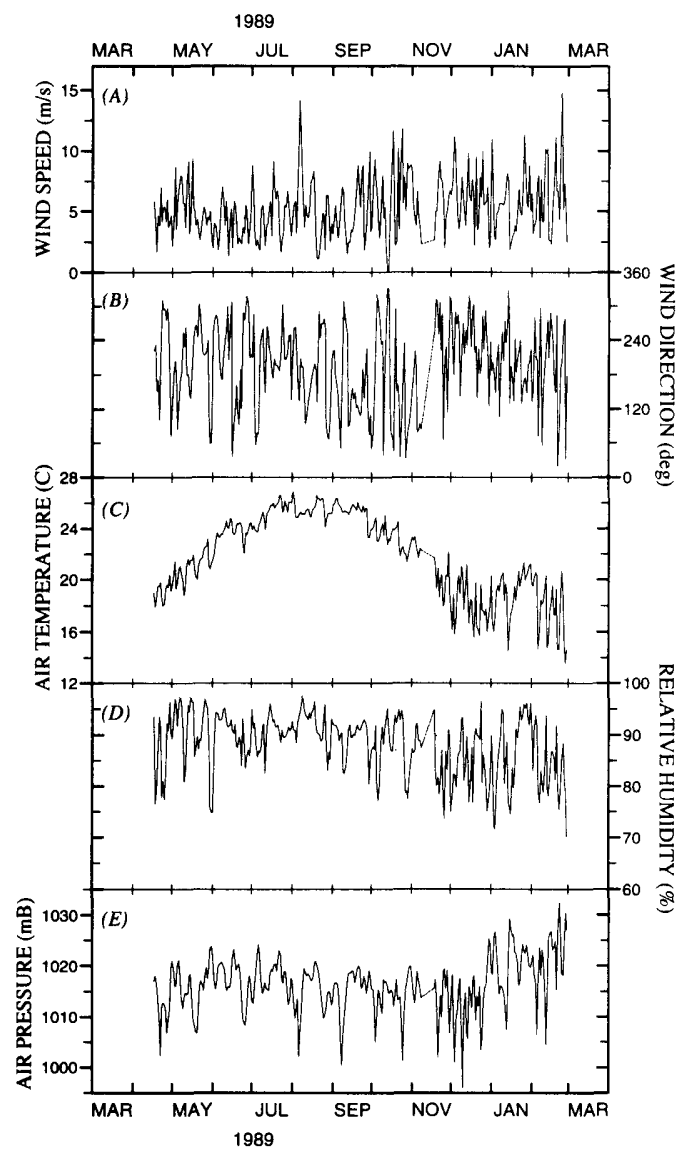

Fig. 4. Meteorological parameters measured on St. David's Head, Bermuda, from April 1989 to February 1990 (data from Knap et al., 1991, 1992). Daily values are reported in these figures: (A) wind speed, (B) wind direction, (C) temperature, (D) relative humidity, and (E) total pressure. These measurements have been carried out at about $10 \mathrm{~m}$ above the ground and at a height of approximately $30 \mathrm{~m}$ above sea level. All values between $09 / 11 / 89$ and $17 / 11 / 89$ are obtained by linear interpolation. 
$\phi_{0}$ exchanges slowly with the atmosphere (due to the chemical buffer) and with the upper thermocline (due to the density cap). In this way, our estimates of NCP in the ML are consistent with (1) the seasonal evolution of observed surface [DIC]; and (2) the rates of vertical mixing and $\mathrm{CO}_{2}$ exchange between sampling dates, constrained by concomitant surface heat fluxes and wind data and by the seasonal evolution of observed temperature profiles. Once eq. (8) is satisfied for a given interval $t_{i}, \mathrm{NCP}$ in the $\mathrm{ML}$ is known $\left(F_{\mathrm{BIO}}^{*}=\phi_{0}\right)$. The rate of gas exchange at the surface is hence integrated diagnostically to give $F_{0}^{*}$. Finally, $F_{\mathrm{UT}}^{*}$ is obtained from the expression of the DIC budget in the ML (eq. (5)), that is, by adding $F_{0}^{*}$ and $F_{\text {BIO }}^{*}$ to the net accumulation term $\left(\mathrm{d}\langle[\mathrm{DIC}]\rangle_{\mathrm{c}} / \mathrm{d} t=F_{\mathrm{TOT}}^{*}\right)$.

2.2.4. Uncertainties in the DIC budget. In our model, errors in the DIC budget are associated with uncertainties in: (1) [DIC] measurements in the ML; (2) the NCP profile below the ML; (3) the exchange rate of $\mathrm{CO}_{2}$ at the sea surface.

(1) Surface measurements of [DIC]. In order to conservatively account for the analytical variability of [DIC] measurements in the ML, the budget is also calculated by introducing an uncer-

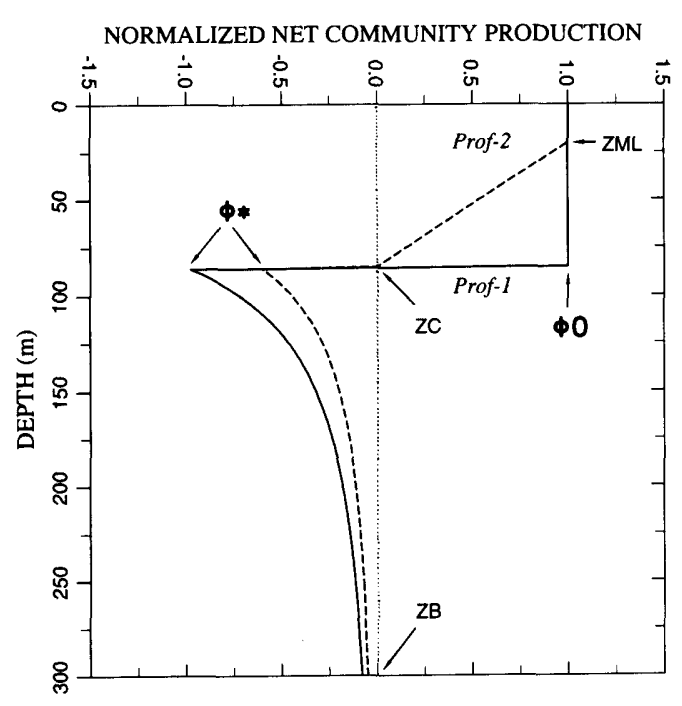

Fig. 5. Profiles of net community production adopted in the diagnostic model. $z_{\mathrm{ML}}$ is the mixed layer depth, $z_{\mathrm{C}}$ is the compensation depth (where gross photosynthesis equals community respiration), and $z_{\mathrm{B}}$ is the bottom of the model domain. Prof -1 is the profile used in the standard model (see text for the other symbols). tainty of $\pm 5 \mu \mathrm{mol} \mathrm{kg}^{-1}$ in surface [DIC] values at the BATS site.

(2) NCP profile below the $M L$. Two different profiles are used to model NCP below the ML. Both assume net autotrophy (net DIC consumption) above a compensation depth $z_{\mathrm{C}}$ and net heterotrophy (net DIC production) below (Fig. 5). In the first profile, NCP is constant and equal to $\phi_{0}$ above $z_{\mathrm{C}}$. Below $z_{\mathrm{C}}$, production is considered negative and decreases with depth according to a power law (from $\phi_{*}$ with exponent $\varepsilon$; Martin et al., 1987, 1993). The equations in this scenario are:

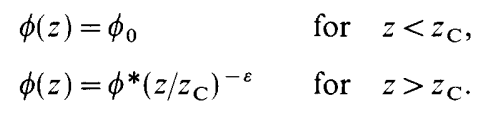

In the second profile, NCP is maximum (equal to $\phi_{0}$ ) only in the ML and declines below linearly to the depth $z_{\mathrm{C}}$. This scenario is expressed by the following equations:

$$
\begin{array}{ll}
\phi(z)=\phi_{0} & \text { for } z<z_{\mathrm{ML}}, \\
\phi(z)=\phi_{0}\left(z_{\mathrm{C}}-z\right) /\left(z_{\mathrm{C}}-z_{\mathrm{ML}}\right) & \text { for } z_{\mathrm{ML}}<z<z_{\mathrm{C}}, \\
\phi(z)=\phi_{*}\left(z / z_{\mathrm{C}}\right)^{-\varepsilon} & \text { for } \quad z>z_{\mathrm{C}} .
\end{array}
$$

The NCP just below the compensation depth $\left(\phi_{*}\right)$ is calculated assuming that DIC consumption above $z_{\mathrm{C}}$ is balanced without delay by DIC production below through respiration.

We further assume that the compensation horizon $\left(z_{C}\right)$ locates at the depth where the concentration of dissolved oxygen in the seasonal thermocline is at saturation. The profiles of $\mathrm{O}_{2}$ anomaly $\left(\left[\mathrm{O}_{2}\right]\right.$ minus its saturation value $\left.\left(\mu \mathrm{mol} \mathrm{kg}^{-1}\right)\right)$ for spring-summer 1989 at the BATS site were thus calculated from $\left[\mathrm{O}_{2}\right]$, temperature, and salinity data reported in Knap et al. (1991, 1992). The values of $z_{\mathrm{C}}$ estimated in this way are reported in Table 1 . The $\mathrm{O}_{2}$ saturation level varied between $68-105 \mathrm{~m}$ from April to September. At these depths, the departure from dissolution equilibrium should be mainly due to local biological activity, rather than to radiative heating (see Jenkins and Goldman [1985] for station S). In the model, we use values of $z_{\mathrm{C}}$ equal to 70,85 , and $100 \mathrm{~m}$ in order to constrain the DIC budget.

Finally, the exponent $\varepsilon$ describing $\mathrm{C}$ remineral- 


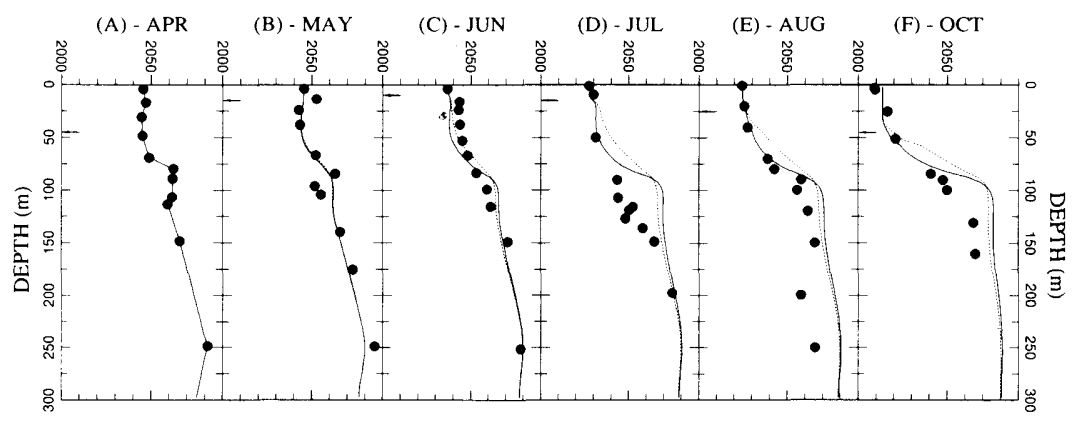

Fig. 6. (a-f) Vertical profiles of dissolved inorganic carbon concentration $\left(\mu \mathrm{mol} \mathrm{kg}^{-1}\right)$ at the BATS site from April to October in 1989 (no data available for September). All values are normalized to 36.6 salinity as in Fig. 3. Circles represent $[D I C]_{s}$ data from Knap et al. $(1991,1992)$. The solid lines are the results of the diagnostic model when the first profile for net community production is adopted (Prof-I on Fig. 5). The dashed lines are the results of this model when the second profile is used (Prof-2 on Fig. 5) (see text). The arrow on each figure locates the depth of the mixed layer.

ization below $z_{\mathrm{C}}$ was estimated from several profiles of sinking flux of particulate organic carbon at the BATS site. Following Martin et al. $(1987,1993)$, the depth-decrease of the POC flux is expressed as a power law $\left(F_{\mathrm{P}}(z) / F_{\mathrm{P}}\left(z_{0}\right)=\left(z / z_{0}\right)^{-b}\right.$, where $b>0)$ and the vertical divergence of $F_{\mathrm{P}}$ is assumed in balance with $\mathrm{C}$ remineralization $(\phi=$ $\left.-\mathrm{d} F_{\mathbf{P}} / \mathrm{d} z\right)$. In our model, $\phi(z) / \phi\left(z_{0}\right)=\left(z / z_{0}\right)^{-(1+b)}$, where $\phi\left(z_{0}\right)=\phi_{*}$ and $1+b=\varepsilon$ (eqs. (9b) and $(10 \mathrm{c}))$. At the BATS site, a free-floating particle trap array was deployed generally for a 3 day period during each cruise (Knap et al., 1991, 1992; Lohrenz et al., 1992). These traps collected particles at 150,200,300, and $400 \mathrm{~m}$. On the basis of POC flux data from January 1989 to August 1990, we have derived a mean profile for the sinking flux ( $n=13-14$, depending on the depth of particle collection). This profile can be reproduced within $\pm 1 \sigma$ with $b \approx 1$ (not shown). This value is similar to that reported for the open ocean composite defined by Martin et al. (1987) and for sinking POC profiles in the northeast Atlantic (Martin et al., 1993). In order to test the influence of $\varepsilon$ on our results, the ML budget of DIC is estimated with $\varepsilon$ equal to $1.5,2$, and 2.5 .

(3) The rate of $\mathrm{CO}_{2}$ exchange at the surface. Uncertainties in thermodynamical relationships and dissociation constants of the $\mathrm{CO}_{2}$ system in seawater can introduce significant errors in the calculation of $\mathrm{pCO}_{2}^{\mathrm{w}}$ from other parameters (Dickson and Riley, 1978; UNESCO, 1987; Copin-
Montégut, 1988; Goyet et al., 1991). Using ML average values of salinity, [DIC], and total alkalinity at the BATS site, we found that the use of different dissociation constants ( $\mathrm{pK}$ 's in Appendix 2) can result in $\mathrm{pCO}_{2}^{\mathrm{w}}$ differences of $12 \mu \mathrm{atm}$ at $19^{\circ} \mathrm{C}$ up to $29 \mu \mathrm{atm}$ at $29^{\circ} \mathrm{C}$. These differences can lead to very distinct estimates of the air-sea exchange of $\mathrm{CO}_{2}$. In our model, we use the pK's that give the highest and lowest $\mathrm{pCO}_{2}^{\mathrm{w}}$ values, to provide error constraints to the computation. Another potential source of error is the use of a constant alkalinity value (surface average [ALK] $=2390 \mu \mathrm{eq} \mathrm{kg}^{-1}$, see Appendix B). Yet, although surface alkalinity near Bermuda is generally correlated with salinity and does not vary regularly over the seasonal cycle (Bates et al., 1992; Keeling, 1993), the time-series at station S reveals that [ALK] normalized to $S$ can be sometimes $10 \mu \mathrm{eq} \mathrm{kg}^{-1}$ lower or higher than this average (Keeling, 1993). A difference of this magnitude is clearly not negligible on $\mathrm{pCO}_{2}^{\mathrm{w}}$ (see, e.g., the partial derivative (8.15) in Appendix B). In order to account for deviations from the average alkalinity value, the DIC budget is also estimated with [ALK] set at 2380 and $2400 \mu \mathrm{eq} \mathrm{kg}^{-1}$ (Table 2).

Finally, the calculation of the piston velocity from wind speed (governing the rate of gas exchange) is also uncertain (eq. (7)). An uncertainty of $\pm 30 \%$ is assumed in this respect in order to provide error constraints on the DIC budget. 
Table 1. Depths of $\mathrm{O}_{2}$ saturation in the seasonal thermocline $\left(z_{C}\right)$ at the BATS site from April to September 1989 (July data excluded, see text)

\begin{tabular}{|c|c|c|c|c|c|c|}
\hline Station & Date & $\begin{array}{c}z_{A_{\mathrm{O}_{2}}>0}{ }^{* *} \\
(\mathrm{~m})\end{array}$ & $\begin{array}{c}\left(A_{\mathrm{O}_{2}}\right)^{*} \\
\left(\mu \mathrm{mol} \mathrm{kg}^{-1}\right)\end{array}$ & $\begin{array}{c}z_{A_{\mathrm{O}_{2}<0}} * * \\
(\mathrm{~m})\end{array}$ & $\begin{array}{c}\left(A_{\mathrm{O}_{2}}\right)^{*} \\
\left(\mu \mathrm{mol} \mathrm{kg}^{-1}\right)\end{array}$ & $\begin{array}{l}z_{\mathrm{C}} \\
(\mathrm{m})\end{array}$ \\
\hline BATS 7 & April & 89.2 & $(3.47)$ & 106.9 & $(-0.29)$ & 106 \\
\hline \multirow[t]{2}{*}{ BATS 8} & May & 66.9 & $(0.28)$ & 84.7 & $(-6.51)$ & 68 \\
\hline & & 66.5 & $(5.53)$ & 85.2 & $(-4.07)$ & 77 \\
\hline BATS 9 & June & 83.9 & $(2.31)$ & 99.5 & $(-3.63)$ & 90 \\
\hline \multirow[t]{2}{*}{ BATS 11} & August & 79.6 & $(15.68)$ & 101.7 & $(-12.80)$ & 92 \\
\hline & & 80.0 & $(6.64)$ & 100.0 & $(-9.56)$ & 88 \\
\hline BATS 12 & September & 92.4 & $(4.40)$ & 110.9 & $(-12.00)$ & 97 \\
\hline
\end{tabular}

* $A_{\mathrm{O}_{2}}\left(\mu \mathrm{mol} \mathrm{kg}{ }^{-1}\right)$ is the oxygen anomaly $\left(\mathrm{O}_{2}\right.$ concentration minus the saturation value at 1 atm) calculated from bottle $\left[\mathrm{O}_{2}\right]$, temperature, and salinity data (from Knap et al (1991)) using the Bunsen absorption coefficient in Weiss (1970) and the state equation in UNESCO (1983).

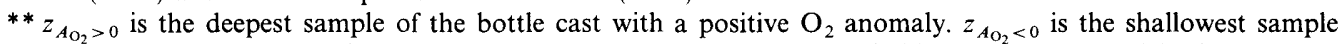
of the bottle cast with a negative $\mathrm{O}_{2}$ anomaly ( 2 casts are sometimes available). $z_{C}$ is calculated by linear interpolation between $z_{A_{\mathrm{O}_{2}}>0}$ and $z_{A_{\mathrm{O}_{2}}<0}$.

Table 2. Budget of dissolved inorganic carbon in the mixed layer at the BATS site for the April-October 1989 period; fluxes are expressed in $\mathrm{mgC} \mathrm{m}^{-3} d^{-1}$ (also in $\mathrm{mgC} \mathrm{m}^{-2} d^{-1}$ for net community production); positive values indicate a net accumulation of DIC in the mixed layer

\begin{tabular}{|c|c|c|c|c|}
\hline Model version & $-F_{0}^{*(1)}$ & $F_{\mathrm{UT}}^{*}(1)$ & $-F_{\mathrm{BIO}}^{*}$ & $F_{\text {TOT }}^{*}(1)$ \\
\hline Standard ${ }^{(2)}$ & -1.1 & 0.6 & $-1.8(-38.9)$ & -2.3 \\
\hline$\Delta[\mathrm{DIC}]=-5 \mu \mathrm{mol} \mathrm{kg}-1$ & -0.8 & 0.4 & $-2.3(-49.2)$ & -2.7 \\
\hline$\Delta[\mathrm{DIC}]=+5 \mu \mathrm{mol} \mathrm{kg}-1$ & -1.4 & 0.8 & $\overline{-1.4}(-29.4)$ & -2.0 \\
\hline Prof- 2 & -1.1 & $\underline{0.9}$ & $\overline{-2.2}(\overline{-47.3})$ & -2.3 \\
\hline$z_{\mathrm{C}}=70 \mathrm{~m}$ & -1.1 & $\overline{0.6}$ & $-1.8(-39.7)$ & -2.3 \\
\hline$z_{\mathrm{C}}=100 \mathrm{~m}$ & -1.1 & 0.6 & $-1.8(-38.8)$ & -2.3 \\
\hline$\varepsilon=1.5$ & -1.1 & 0.6 & $-1.8(-38.9)$ & -2.3 \\
\hline$\varepsilon=2.5$ & -1.1 & 0.6 & $-1.8(-38.9)$ & -2.3 \\
\hline $\mathrm{DM}+\mathrm{HA}^{(3)}$ & -0.3 & $\underline{0.1}$ & $-2.1(-43.3)$ & -2.3 \\
\hline$\Delta[\mathrm{ALK}]=-10 \mu \mathrm{eq} \mathrm{kg}^{-1}$ & -1.5 & 0.9 & $-1.7(-36.1)$ & -2.3 \\
\hline$\Delta[\mathrm{ALK}]=10 \mu \mathrm{eq} \mathrm{kg}^{-1}$ & $\overline{-0.6}$ & 0.3 & $-2.0(-45.5)$ & -2.3 \\
\hline$\gamma_{\mathrm{vP}}=0.7$ & -0.8 & 0.4 & $-1.9(-38.4)$ & -2.3 \\
\hline$\gamma_{\mathrm{vP}}=1.3$ & -1.4 & 0.8 & $-1.7(-37.8)$ & -2.3 \\
\hline
\end{tabular}

(1) $F_{0}^{*}, F_{\mathrm{UT}}^{*}$, and $F_{\mathrm{BIO}}^{*}$ are DIC fluxes related to the air-sea exchange of $\mathrm{CO}_{2}$, the upward transport of DIC at the base of the mixed layer, and the net community production, respectively. $F_{\mathrm{UT}}^{*}$ is derived from $F_{\mathrm{UT}}^{*}=F_{\mathrm{TOT}}^{*}+F_{\mathrm{BIO}}^{*}+F_{0}^{*}$, where $F_{\mathrm{TOT}}^{*}$ is the net [DIC] drawdown calculated by the model in each model version. The underlined values are the minimum and the maximum for each flux.

(2) The standard version is defined as follows: (a) the profile 1 for NCP (Prof- 1 ) is adopted, (b) the compensation depth $\left(z_{\mathrm{C}}\right)$ is $85 \mathrm{~m}$, (c) the exponent for the remineralization profile $(\varepsilon)$ is 2 , (d) uncertainties in mixed layer [DIC] and $[\mathrm{ALK}]$ are nil $\left(\Delta[\mathrm{DIC}]=\Delta[\mathrm{ALK}]=0 \mu \mathrm{mol} \mathrm{kg}^{-1}\right.$ ), (e) the dissociation constants of Roy et al. (1993) for carbonic acid and Dickson (1990) for boric acid are used, and ( $\mathrm{g}$ ) the multiplier for the piston velocity is $1\left(\gamma_{\mathrm{vP}}=1\right)$.

(3) The symbols DM + HA indicate the result when the pK's of Dickson and Millero (1987) for carbonic acid and the $\mathrm{pK}$ of Hansson (1972) for boric acid, are used. 


\section{Results}

\subsection{Evidence of in situ removal of DIC in the spring-summer mixed layer}

In the Northwestern Sargasso Sea, the summertime heating is able to bring $\mathrm{pCO}_{2}^{\mathrm{w}}$ above saturation with respect to the atmosphere (Bates et al., 1992, 1993; Keeling, 1993). Net outgassing of $\mathrm{CO}_{2}$ can then occur for this period. In order to estimate its maximum effect on surface [DIC] at the BATS site for 1989, the continuity eq. (1) is solved without the biological flux, with $v_{\mathrm{P}}$ multiplied by 1.3 , and with $\mathrm{pCO}_{2}^{\mathrm{w}}$ calculated using the $\mathrm{pK}$ 's of Roy et al. (1993) for carbonic acid and the pK of Dickson (1990) for boric acid (these give the highest $\mathrm{pCO}_{2}^{\mathrm{w}}$ among the $\mathrm{pK}$ 's considered here, see Appendix B). In this case (Fig. 3), the concentration decreases by ca. $10 \mu \mathrm{mol} \mathrm{kg}{ }^{-1}$ from April to October (precipitous [DIC] increases are due to short-term mixing events with relatively rich waters of the thermocline). If the biological exchange is neglected, the efflux of $\mathrm{CO}_{2}$ to the atmosphere can therefore explain a maximum of only about $30 \%$ of the observed [DIC] decrease in the $\mathrm{ML}\left(\approx 30 \mu \mathrm{mol} \mathrm{kg} \mathrm{kg}^{-1}\right)$.

\subsection{Imbalance of DIC in the spring-summer mixed layer}

3.2.1. The standard model. In the standard version, the compensation depth is fixed to $85 \mathrm{~m}$, the exponent for deep remineralization is 2 , the (most recent) dissociation constants of Roy et al. (1993) and Dickson (1990) are used to compute $\mathrm{pCO}_{2}^{\mathrm{w}}$, and the values of $v_{\mathrm{p}}$ are assumed to have $0 \%$ uncertainty. The seasonal evolution of surface [DIC] calculated in this way is shown by line B on Fig. 3 (with $a_{1}=1 \mu \mathrm{mol} \mathrm{kg}^{-1}$, this line passes at $\pm 1 \mu \mathrm{mol} \mathrm{kg}^{-1}$ around the data points). The evolution of the [DIC] profile in the top $300 \mathrm{~m}$ produced by the standard model is further reported on Fig. 6. The model simulates reasonably well the [DIC] gradients just below the ML. In this regard, a better fit is obtained if NCP is set equal to a constant value above $z_{\mathrm{C}}$ (Prof-1 in Fig. 5). Note however that the model poorly accounts for low [DIC] values in the 90-150 m stratum, especially in July. For this month, salinity was high and $\left[\mathrm{O}_{2}\right]$ was low in this stratum, compared with June and August (Knap et al., 1991). This could result from the lateral intrusion of a high salinity water (Siegel et al., 1995). Yet, the model should simulate with a good degree of confidence DIC mixing between the ML and the upper thermocline (i.e., above $\approx 60 \mathrm{~m}$ ).

The DIC budget of the standard model is summarized in Table 2 and depicted in Fig. 7A. Fluxes are expressed in $\mathrm{mgC} \mathrm{m}^{-3} \mathrm{~d}^{-1}$. The [DIC] decrease of ca. $30 \mu \mathrm{mol} \mathrm{kg}^{-1}$ from April to October corresponds to a mean daily rate of removal of $2.3 \mathrm{mgC} \mathrm{m}^{-3} \mathrm{~d}^{-1}$ in the ML. If profile 1 is used to model the biological exchange (Fig. 5), about $80 \%$ of this removal should be explained by net community production. The remaining drawdown is due to $\mathrm{CO}_{2}$ outgassing to the atmosphere, which provides an additional loss of about $1 \mathrm{mgC}$ per $\mathrm{m}^{3}$ in the ML per day. Vertical transport enriches the ML [DIC] by about $0.6 \mathrm{mgCm}^{-3} \mathrm{~d}^{-1}$. This compensates for only ca. $20 \%$ of the losses due to the biological uptake and the gas efflux at the sea surface.

3.2.2. Sensitivity of the DIC budget on model parameters. The sensitivity analysis shows that the estimate of net community production in the ML remains well-constrained, i.e., between 1.4-2.3 $\mathrm{mgC} \mathrm{m}^{-3} \mathrm{~d}^{-1}$ (Table 2 and Fig. 7B) (note however that all the possible combinations between model parameters are not considered). The lowest NCP is obtained when surface [DIC] data are increased by $5 \mu \mathrm{mol} \mathrm{kg}^{-1}$. In this case, the required surface production is lower than in the standard model, since the [DIC] drawdown is less pronounced (cf. line B1 in Fig. 3). Moreover, due to higher [DIC]'s in the $\mathrm{ML}, \mathrm{CO}_{2}$ out-

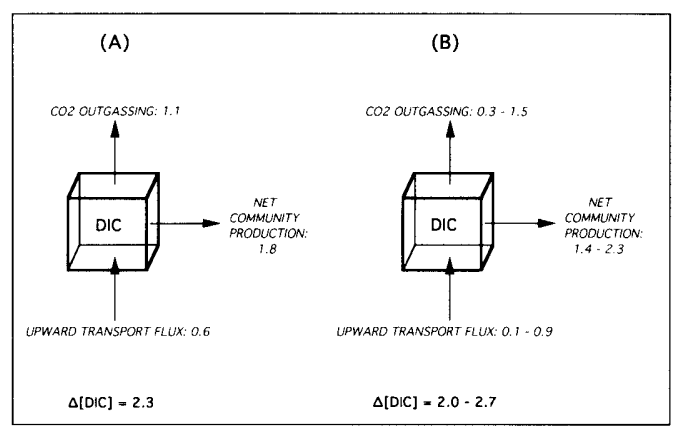

Fig. 7. Budget of dissolved inorganic carbon in the mixed layer at the BATS site for the April-October period in 1989: (A) results from the standard version of the diagnostic model; (B) results produced by accounting for the uncertainties in this model. Fluxes are expressed as daily averages, $\left(\mathrm{mgC} \mathrm{m}^{-3} \mathrm{~d}^{-1}\right)$ (see text). 
gassing ( $1.4 \mathrm{mgC} \mathrm{m}^{-3} \mathrm{~d}^{-1}$ ) is higher than in the standard case. About $30 \%$ of the losses due to biological uptake and gas efflux to the atmosphere are compensated by mixing with DIC-rich waters of the seasonal thermocline $\left(0.8 \mathrm{mgC} \mathrm{m}^{-3} \mathrm{~d}^{-1}\right)$. In this scenario, the budget is therefore $-1.4-1.4+0.8 \approx-2.0 \mathrm{mgC} \mathrm{m}^{-3} \mathrm{~d}^{-1}$. The largest NCP $\left(2.3 \mathrm{mgC} \mathrm{m}^{-3} \mathrm{~d}^{-1}\right)$ is obtained when surface [DIC] data are decreased by $5 \mu \mathrm{mol} \mathrm{kg}^{-1}$. As expected, the outgassing flux in this case $\left(0.8 \mathrm{mgC} \mathrm{m}^{-3} \mathrm{~d}^{-1}\right)$ is lower than in the standard model, while vertical transport from thermocline water $\left(0.4 \mathrm{mgC} \mathrm{m}^{-3} \mathrm{~d}^{-1}\right)$ balances a smaller fraction of the DIC losses (ca. 15\%). The budget in this scenario is thus $-2.3-0.8+0.4 \approx$ $-2.7 \mathrm{mgCm}^{-3} \mathrm{~d}^{-1}$.

When profile 2 is adopted to model the biological exchange (Fig. 5), NCP declines just below the ML. Hence, DIC in the upper thermocline (between $z_{\mathrm{ML}}-z_{\mathrm{C}}$, where $0<\phi<\phi_{0}$ ) is less consumed than if profile 1 is used (Figs. 6C-F). Accordingly, vertical mixing, that tends to increase surface [DIC], competes more efficiently with the biological uptake, since the [DIC] gradient at the base of the ML is more pronounced. In this case, a larger value of $\phi_{0}\left(2.2 \mathrm{mgC} \mathrm{m}^{-3} \mathrm{~d}^{-1}\right)$ is thus required to account for the observed [DIC] drawdown. The transport rate at the base of the ML $\left(0.9 \mathrm{mgC} \mathrm{m}^{-3} \mathrm{~d}^{-1}\right)$ is also the largest among the model versions considered (Table 2 ). DIC budgets estimated using a different compensation depth $z_{\mathrm{C}}$ (between 70-100 m) and a different exponent $\varepsilon$ for deep remineralization (between 1.5-2.5), are similar to that produced by the standard model (Table 2). This is expected, since the base of the ML remains shallower than $z_{C}$ during the course of the simulation (Figs. 6,9). The surface biological production required using the $\mathrm{pK}$ 's that produce the lowest $\mathrm{pCO}_{2}^{\mathrm{w}}$ 's (Fig. 8) and using different [ALK]'s, is relatively close to the standard value of $1.8 \mathrm{mgC} \mathrm{m}^{-3} \mathrm{~d}^{-1}$ (the difference depends on the fraction of the [DIC] drawdown than can be explained by net outgassing). Similarly, changes in the piston velocity $( \pm 30 \%)$ has a minimal effect on NCP estimates $\left(1.7-1.9 \mathrm{mgC} \mathrm{m}^{-3} \mathrm{~d}^{-1}\right)$. The low sensitivity of the required NCP to uncertainties in $\mathrm{pCO}_{2}^{\mathrm{w}}$ 's and $v_{\mathrm{P}}$ is related to the fact that [DIC] variations associated with the $\mathrm{CO}_{2}$ exchange at the surface are buffered according to the Revelle factor (partial derivative (8.14) in Appendix B).

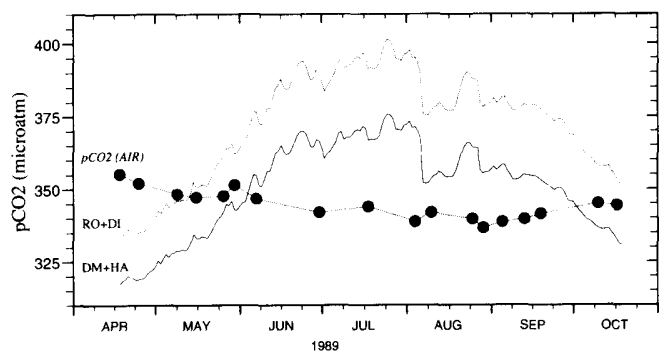

Fig. 8. Partial pressures of $\mathrm{CO}_{2}$ in air and in surface water in the northwestern Sargasso Sea from April to October 1989. The partial pressures in air are calculated from $\mathrm{CO}_{2}$ mixing ratio replicates in dry air at the Bermuda East station from the NOAA flask network (data from WMO/GAW, 1992). The correction for water vapor was made from total pressure, relative humidity, and air temperature measured on St. David's Head, Bermuda (see Figs. 4C-E). The partial pressures in seawater are computed by the diagnostic model: (1) the line labelled with $\mathrm{RO}+\mathrm{DI}$ is the result when using dissociation constants of Roy et al. (1993) for carbonic acid and the pK of Dickson (1990) for boric acid: (2) the line labelled with $\mathrm{DM}+\mathrm{HA}$ is the result when using dissociation constants of Dickson and Millero (1987) for carbonic acid and the $\mathrm{pK}$ of Hansson (1972) (fitted to the equation of Millero, 1979) for boric acid (see text).

The standard model and the sensitivity analysis indicate that the [DIC] decrease mostly result from net community production. Estimates of NCP account for $71-93 \%$ of this decrease, with the range attributed to uncertainties in the DIC budget. The efflux of $\mathrm{CO}_{2}$ from the warm supersaturated $\mathrm{ML}$ (inducing losses between 0.3-1.5 $\mathrm{mgC} \mathrm{m}^{-3} \mathrm{~d}^{-1}$ ) contributes to $14-68 \%$ of the surface drawdown. Finally, DIC injection through the base of the ML compensates for only 4-29\% of the losses due to the biological uptake and the $\mathrm{CO}_{2}$ efflux to the atmosphere.

\section{Discussion}

The spring-summer net community production in the ML of the subtropical gyre can be inferred from surface [DIC] measurements thanks to the long equilibration time with atmospheric $\mathrm{CO}_{2}$ (about 1 year, see Broecker and Peng (1982)) and to the density cap below the ML that prevents efficient mixing with thermocline waters for these seasons. In this respect, the surface production 
estimated from $\left[\mathrm{O}_{2}\right]$ data at station $\mathrm{S}$ has remained unconstrained (Spitzer and Jenkins, 1989). This is due to the fact that dissolved $\mathrm{O}_{2}$ equilibrates much more quickly (about 1 month) with the atmosphere than the DIC pool (Broecker and Peng, 1982). Yet the spring-summer NCP in the autotrophic layer estimated here (between $120-195 \mathrm{mgC} \mathrm{m}^{-2} \mathrm{~d}^{-1}$ in the top $85 \mathrm{~m}$, according to the uncertainty in [DIC] measurements) can be compared to net productions in the euphotic zone inferred for about the same period from the subsurface $\mathrm{O}_{2}$ maximum at station $\mathrm{S}$ (Jenkins and Goldman, 1985; Musgrave et al., 1988; Spitzer and Jenkins, 1989). Since we are uncertain if net production near Bermuda is nitrate-based or supported by other nitrogeneous compounds, a photosynthetic quotient between $1-1.5$ is used to convert $\mathrm{O}_{2}$ productions into organic $\mathrm{C}$ productions (Laws, 1991; Williams and Robertson, 1991). Estimates of net $\mathrm{O}_{2}$ productions of Jenkins and co-workers (3.0-7.1 $\mathrm{mol} \mathrm{O}_{2} \mathrm{~m}^{-2} \mathrm{yr}^{-1}$ ) should be equivalent to $66-233 \mathrm{mgC} \mathrm{m}^{-2} \mathrm{~d}^{-1}$. The $\mathrm{NCP}$ in the euphotic zone inferred in this study is thus within earlier estimates of production obtained from $\left[\mathrm{O}_{2}\right]$ changes in situ.

The depth-integrated NCP in the ML amounts in this study to $29-49 \mathrm{mgC} \mathrm{m}^{-2} \mathrm{~d}^{-1}$ (Table 2). This should be a lower estimate, given that the mean flow should bring waters with slightly higher [DIC] from the northeast into the mixed layer south off Bermuda (see above). If the photosynthetic assimilation of carbon and nitrogen and the oxidation of organic matter proceed with Redfield stoichiometry, NCP during springsummer requires approximately $370-620 \mu \mathrm{mol} \mathrm{N}$ $\mathrm{m}^{-2} \mathrm{~d}^{-1}$. According to a classical paradigm, most of this biological requirement should be met by mixing with deep, nutrient-rich waters (McCarthy and Carpenter, 1983). At the BATS site, the nitrocline (estimated from the $0.5 \mu \mathrm{mol} \mathrm{kg}^{-1}$ isopleth of the $\left[\mathrm{NO}_{2}^{-}\right]+\left[\mathrm{NO}_{3}^{-}\right]$profiles) lies however below $80 \mathrm{~m}$ from April to October in 1989. This is much deeper than the base of the ML for this period (Fig. 9). The question then arises about the possible sources of nitrogen to support the biological production in this layer.

It has been suggested that unsampled, pulse-like supplies of nutrients to the euphotic zone could support a large fraction of the annual primary production in nitrogen-poor ocean waters (Platt and Harrison, 1985; Malone et al., 1993). Accord-

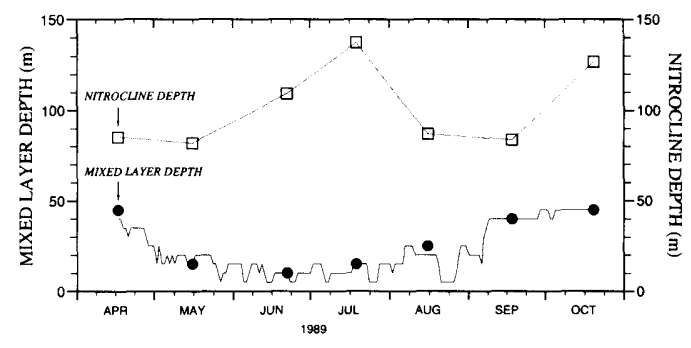

Fig. 9. Depths of the mixed layer and of the nitrocline at the BATS site from April to October 1989. Circles represent the data from Knap et al. (1991, 1992) and the line is the result of the physical model (when corrected by temperature profiles measured in situ). The depth of the mixed layer is estimated using a $\Delta T=0.5^{\circ} \mathrm{C}$ criterion. Squares represent the depth of the nitrocline as the $0.5 \mu \mathrm{mol} \mathrm{kg}^{-1}$ isopleth of $\left[\mathrm{NO}_{2}^{-}\right]+\left[\mathrm{NO}_{3}^{-}\right]$profiles (data from Knap et al., 1991, 1992) (see text).

ing to Jenkins and Goldman (1985), this could explain why new production estimated from integrative geochemical approaches (based on in situ variations of chemical species) may be much larger than discrete rate measurements (e.g., via the ${ }^{14} \mathrm{C}$ technique). Since mixing with deep waters should also transport DIC to the surface, a net input of preformed nutrients, more precisely, is required. The physical model we used (which is driven by short-term variations in meteorological forcing, $<1$ day, concomitant with the sampling period at sea) however suggests that the ML at the BATS site has never reached the nitrocline for spring-summer 1989 (Fig. 9). Even when hurricane Dean passed through the region in early August, the base of the ML remained several tens of meters above the nutrient-rich water, despite the sudden drop of SST in the model (see Fig. 1). In this respect, only a very small increase in nitrate concentration was detected in the ML after this transient event (to $0.05 \mu \mathrm{M}$, see Malone et al., 1993). Processes other than pulse-like inputs of nutrients from deep water should therefore be responsible for the biologically-mediated [DIC] drawdown at the BATS site.

The atmospheric deposition of nitrogen and $\mathrm{N}_{2}$ fixation could also stimulate organic production in the euphotic zone of the open sea (Eppley and Peterson, 1979; McCarthy and Carpenter, 1983). Michaels et al. (1993) have reported a mean rate of nitrogen deposition via rainfalls on Bermuda 
of ca. $68 \mu \mathrm{mol} \mathrm{N} \mathrm{m}{ }^{-2} \mathrm{~d}^{-1}\left(\mathrm{NO}_{3}^{-}+\mathrm{NH}_{4}^{+}\right)$from October 1988 to June 1991. This flux represents only $10-20 \%$ of the $\mathrm{N}$ requirement to support the biological production in the ML at the BATS site from April to October 1989. Including a flux of 6-19 $\mu \mathrm{molm}^{-2} \mathrm{~d}^{-1}$ for dry deposition to the Sargasso Sea (Duce, 1986), the total input via atmospheric deposition should be only slightly higher. Although this input could contribute to a significant portion of the $\mathrm{N}$ requirement in the ML, existing data thus indicate that it is insufficient to meet the whole demand. Nitrogen fixation by Oscillatoria (Trichodesmium), presumably the main $\mathrm{N}_{2}$ fixers in marine plankton (Carpenter, 1983), could introduce an additional flux of $0.5-5 \mu \mathrm{mol} \mathrm{N} \mathrm{m} \mathrm{m}^{-2} \mathrm{~d}^{-1}$ into the euphotic zone of the Sargasso Sea (Duce, 1986). The largest value amounts to only ca. $1 \%$ of the required nitrogen. These estimates of $\mathrm{N}_{2}$ fixation, however, are quite uncertain (Duce, 1986; Duce et al., 1991) and the diazotrophic activity in the marine sunlit zone is increasingly considered as higher as previously thought (Karl et al., 1992).

The recycling of organic matter in situ could contribute to the nitrogen requirement. In order to assess the efficiency in the recycling of organic carbon in the ML, net community production values calculated in this study are compared to surface rates of primary production measured via ${ }^{14} \mathrm{C}$ incubations at the BATS site for springsummer 1989 (Fig. 10). The two measurements of production are relatively close to each other. The mean primary production in the $\mathrm{ML}$ is $3.4 \mathrm{mgC}$ $\mathrm{m}^{-3} \mathrm{~d}^{-1}$ for the April-October period, while a median value of $1.8 \mathrm{mgC} \mathrm{m}^{-3} \mathrm{~d}^{-1}$ is most representative of NCP estimates (Table 2). The ratio between NCP and total primary production is thus approximately 0.5 , that is, the fraction of organic carbon respired in the ML would amount to $50 \%$. If we assume that NCP and new production, sensu Dugdale and Goering (1967), are equivalent, this fraction is equal to $1-f$, where $f$ is the ratio between new and total productions (Eppley and Peterson, 1979). It is worth comparing this fraction to previous estimates of the $f$-ratio in the shallow waters near Bermuda. Two kinds of estimates based on in situ measurements at $25 \mathrm{~m}$ at station $\mathrm{S}$ are available. First, $f$-ratios between $0.0-0.2$, with a mean value of 0.08 , were reported by Dugdale and Goering (1967) from in vitro assimilation rates of $\mathrm{NO}_{3}^{-}$and $\mathrm{NH}_{4}^{+}$between

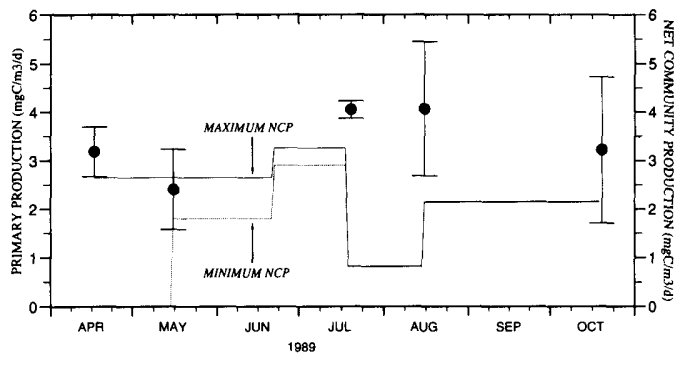

Fig. 10. Primary production and net community production in the mixed layer at the BATS site from April to October 1989. Circles represent mean values of primary production measured in the mixed layer and horizontal bars indicate one standard deviation around these values. Primary production was measured via in situ dawn-to-dusk incubations with ${ }^{14} \mathrm{C}$ (dark bottle rates were substracted from light bottle rates in order to correct for non-photoautotrophic fixation and/or adsorption) (data from Knap et al., 1991, 1992). The dashed and the solid lines are produced by the diagnostic model and refer respectively to the lowest and the largest net community productions required to account for the observed [DIC] drawdown (inferred from the sensitivity analysis on model parameters, see text).

September-January. Second, Platt and Harrison (1985) estimated this ratio between $0-0.8$, with an annual average of ca. 0.3 , using $\left[\mathrm{NO}_{3}^{-}\right]$data. The $f$-ratio that would reconciliate net community and primary productions in this study $(\simeq 0.5)$ is thus larger than these two estimates.

Net community and new productions are, however, not strictly equivalent concepts. The first is based on the cycle of photosynthetically fixed C through the trophic web, whereas the second is based on the source of nutrients (logically nitrogen) for primary production. Therefore, if $\mathrm{C}$ and $\mathrm{N}$ are assimilated and/or recycled with different rates (transgressing the standard Redfield model), both concepts of production are clearly not similar. In this respect, the regeneration of nutrients in the ML of the northwestern Sargasso Sea is presumably high (Menzel and Ryther, 1960; Malone et al., 1983). Thus, NCP estimates of $\simeq 1-2 \mathrm{mgC} \mathrm{m}^{-3} \mathrm{~d}^{-1}$ inferred in this study would suggest that carbon is recycled less efficiently than nitrogen. Likewise, the elevated consumption of carbon relative to nitrogen observed during phytoplankton blooms in high latitude ML seem best explained by biological processes that recycle nitrogen more efficiently that carbon (Sambrotto 
et al., 1993). Carbon overconsumption may thus exist in both nutrient-poor and nutrient-rich regions of the open ocean (Toggweiler, 1993). If this is the case, the organic material leaving the ML should be enriched in $C$ relative to $N$. There is an indication that the $\mathrm{C}: \mathrm{N}$ ratio of sinking particles generally increases with depth (below $150 \mathrm{~m}$ ) at the BATS site (Lohrenz et al., 1992). Moreover, a large fraction of photosynthetically fixed $C$ could be sequestened in the dissolved organic matter in this region (Carlson et al., 1994). The lateral transport of DIC into the ML at the BATS site must be investigated (Michaels et al., $1994 \mathrm{~b}$ ), and more accurate estimates of $\mathrm{N}_{2}$ fixation (Karl et al., 1992), dry deposition (Duce, 1986), and wet deposition (Cornell et al., 1995), are needed, however, before dealing further with the amplitude of the apparent $\mathrm{C}$ overconsumption.

\section{Conclusions}

The surface concentration of dissolved inorganic carbon at the BATS site in the northwestern Sargasso Sea decreased by about $30 \mu \mathrm{mol} \mathrm{kg}^{-1}$ from May to October in 1989. In order to explain this decrease, we have developed a diagnostic model for the heat and DIC budgets in the upper water column by assuming a vertical balance. Accordingly, the application of this model could be extended to other tracers (e.g., $\mathrm{O}_{2}$ ), provided that concentration data are available with sufficient temporal resolution, and to regions where such a balance holds. From a sensitivity analysis on model parameters, the [DIC] decrease at the BATS site is mostly explained $(71-93 \%)$ by a net community production averaging $1.4-2.3 \mathrm{mgC}$ $\mathrm{m}^{-3} \mathrm{~d}^{-1}$. Heating during this period has also contributed to the [DIC] drawdown via $\mathrm{CO}_{2}$ outgassing $(14-68 \%)$. The imbalance results from the incomplete compensation of these two losses $(<30 \%)$ by mixing with DIC-rich waters of the seasonal thermocline. The required net community production is a lower estimate, since the mean flow should transport DIC-rich waters from the northeast and hence depress the amplitude of the observed [DIC] drawdown. This production is unexpected given the very low surface concentration of nitrate and phosphate in the area. Wet deposition of nitrogen from the atmosphere could contribute to $10-20 \%$ of the nitrogen requirement to support this production. Unsampled, transient supplies of nutrients from deep waters to the surface and $\mathrm{N}_{2}$ fixation appear however insufficient to meet the remaining demand. On the other hand, the rates of primary production measured in the mixed layer may account for the [DIC] decrease, if most $(>50 \%)$ of the photosynthetically fixed $C$ is not respired in this layer. The paradox of an elevated net community production in a highly regenerative system, where phytoplankton production and consumption are closely coupled, could result from a more efficient recycling of nutrients relative to carbon.

\section{Acknowledgments}

The authors would like to express their gratitude to the personnel at the Bermuda Biological Station for Research who made the measurements at BATS, i.e., Anthony Knap, Anthony Michaels, Rachael Dow, Rodney Johnson, Kjell Gundersen, Jens Sorensen, and to other visiting scientists who participated in sampling, i.e., Merritt Tuel, Steve Lohrenz, Vernon Asper, George Knauer, Hugh Ducklow, and Helen Quinby. A first version of the manuscript benefited from the critical views of Michael Bender and Nicolas Gruber. Discussion with Anthony Michaels and Rodney Johnson was also deeply appreciated. We finally thank the Commissariat à l'Energie Atomique (CEA, France) for the computing facilities and the hospitality provided at the Laboratoire de Modélisation du Climat et de l'Environnement. This study was supported by a research bursary, granted to the first author, from the Commission of the European Communities as part of the EPOCH programme (contract ERB 4001 GT 911204). This is CFR contribution No. 1656 and BBSR contribution No. 1378.

\section{Appendix A}

The state variables of the physical model of Gaspar et al. (1990) are temperature $(T)$, salinity $(S)$, horizontal velocity $(V)$, and turbulent kinetic energy (TKE). In this study, we have neglected salinity changes and fixed it to its surface average value of 36.6 (salinity variations at the BATS site have a modest effect on the equilibria of the 
$\mathrm{CO}_{2}$ /carbonate system, see Appendix B). The state equation is solved according to the polynomial in UNESCO (1983). The conservation equation for each state variable $(E)$ has the general form:

$\frac{\partial E(z, t)}{\partial t}=\frac{\partial F_{\mathrm{E}}(z, t)}{\partial z}+P_{\mathrm{E}}(z, t)$,

where $F_{\mathrm{E}}(z, t)$ is the local vertical flux (in the water column, $\left.F_{\mathrm{E}}(z, t)=k(z, t) \partial E(z, t) / \partial z\right)$ and $P_{\mathrm{E}}$ is the local rate of net production for $E$. In the heat equation, this latter term is associated with radiative heating:

$P_{\mathrm{T}}(z, t)=\frac{-1}{\rho^{\mathrm{w}} C_{\mathrm{p}}^{\mathrm{w}}} \frac{\partial E_{\mathrm{d}}(z, t)}{\partial z}$,

where $\rho^{\mathrm{w}}$ is a reference density for seawater and $C_{\mathrm{p}}^{\mathrm{w}}$ is the specific heat at constant pressure (in this study, $\rho_{\mathrm{w}}=1025 \mathrm{~kg} \mathrm{~m}^{-3}$ and $C_{\mathrm{p}}^{\mathrm{w}}=4000 \mathrm{~J} \mathrm{~kg}^{-1}$ $\left.\mathrm{K}^{-1}\right) . E_{\mathrm{d}}\left(\mathrm{W} \mathrm{m}^{-2}\right)$ is the downwelling solar irradiance, calculated as follows. The solar constant is set equal to $1339 \mathrm{~W} \mathrm{~m}^{-2}$. The solar declination and elevation above the horizon are derived from the formulae in Kirk (1983, pp. 33). The transmission of the direct and diffuse components of $E_{\mathrm{d}}$ through the air column are hence computed as described in Musgrave et al. (1988). At the sea surface, a Fresnel reflection is assumed for the direct radiation. A constant reflection coefficient $(6 \%)$ is prescribed on the other hand for the transmission of the diffuse component (Ivanoff, 1977). Hence, the propagation of $E_{\mathrm{d}}$ through the water column is parametrized using the equation in Paulson and Simpson (1977). This accounts for the strong absorption of long wavelength radiation in the top meters of the surface ocean. In this equation, we have introduced the constants of the Jerlov optical type IA. These were previously adopted for station S (Jenkins and Goldman, 1985; Spitzer and Jenkins, 1989).

Eq. (7.1) is finite differenced on a 300 -m-thick staggered grid $(\Delta z=5 \mathrm{~m})$, with $T$ and $V$ computed at the center of each cell, and TKE and $k$ determined at cell boundaries (Gaspar et al., 1990). The resolution of the inertial period (about $23 \mathrm{~h}$ at the latitude of the BATS site) appeared essential for the model to reproduce the seasonal cycle of temperature in the mixed layer; a time step of $15 \mathrm{~min}$ is used as in Gaspar et al. (1990). The rate of radiative heating, correction flux $H_{\mathrm{T}}$, gas exchange, and net community production (see text) are solved according to a simple explicit scheme. The inertial rotation in the momentum equation is taken into account via a two-time step, implicit algorithm (Mellor and Durbin, 1975). Finally, shear production, buoyancy flux, and Kolmogorov dissipation in the TKE equation are solved following an implicit scheme. The integrations hence proceed via the inversion of tridiagonal matrices.

\section{Appendix B}

Wind speed, wind direction, air temperature, relative humidity, and total pressure have been measured at St. David's Head, Bermuda, on top of a 10-m-tall sampling tower located at ca. $30 \mathrm{~m}$ above sea level (Figs. 4A-E). We use the 4-h average wind data and daily values for the other parameters published in the BATS data reports (Knap et al. 1991, 1992). The meteorological data are not available for the $09 / 11 / 89-17 / 11 / 89$ period ( 9 days). A linear interpolation is hence carried out for each parameter during this period (see dashed line on Figs. 4A-E). This has no effect on the DIC budget which is estimated for springsummer 1989 only.

\section{Heat fluxes and wind stresses}

The net flux of heat from air to sea $\left(F_{\mathrm{T}}\right)$ is the sum of fluxes of latent heat $\left(F_{\mathrm{LE}}\right)$, sensible heat $\left(F_{\mathrm{SE}}\right)$, and net IR radiation $\left(F_{\mathrm{IR}}\right)\left(\mathrm{W} \mathrm{m}^{-2}\right)$ :

$F_{\mathrm{T}}=F_{\mathrm{LE}}+F_{\mathrm{SE}}+F_{\mathrm{IR}}$.

$F_{\mathrm{LE}}$ is related to the specific humidity of air $\left(q^{*}\right.$, dimensionless) through (Niiler and Kraus, 1977):

$F_{\mathrm{LE}}=-\rho^{\mathrm{a}} C_{\mathrm{D}} W_{10}\left\{L_{\mathrm{v}}\left(q_{\mathrm{s}}^{*}-q^{*}\right)\right\}$.

$\rho^{\mathrm{a}}$ is a reference density for air (in this study $\left.\rho^{\mathrm{a}}=1.25 \mathrm{~kg} \mathrm{~m}^{-3}\right), W_{10}\left(\mathrm{~m} \mathrm{~s}^{-1}\right)$ is the wind speed measured at $10 \mathrm{~m}, L_{\mathrm{V}}$ is the latent heat of vaporization (set constant and equal to $2.45 \times 10^{6} \mathrm{~J} \mathrm{~kg}^{-1}$ ), and $q_{\mathrm{s}}^{*}$ is the specific humidity at saturation at the sea surface temperature (SST). $C_{\mathrm{D}}$ (dimensionless) is a transfer coefficient. This is taken identical in the bulk formulae for the fluxes of latent and sensible heat, and for the wind stress (Niiler and Kraus, 1977). We use a value of 
$1.0 \times 10^{-3}$; this produces an RMS error of model SST of ca. $0.3^{\circ} \mathrm{C}$ for the April-October period (without the correction flux $H_{\mathrm{T}}$, see text). When the value of $C_{\mathrm{D}}$ is fixed between $0.8 \times 10^{-3}$ $1.4 \times 10^{-3}$, this error remains less than $0.7^{\circ} \mathrm{C}$ and the maximal error in SST is $\leqslant 1^{\circ} \mathrm{C}$ for this period.

The specific humidities $\left(q^{*}\right.$ and $\left.q_{\mathrm{s}}^{*}\right)$ are related to the partial pressures of water vapor, respectively, below saturation $\left(P^{\mathrm{v}}\right.$, in $\left.\mathrm{mB}\right)$ and at saturation at the SST $\left(P_{\mathrm{s}}^{\mathrm{v}}(\mathrm{SST})\right.$, in $\left.\mathrm{mB}\right)$ :

$$
\begin{aligned}
& q^{*}=\frac{\varepsilon_{\mathrm{m}} P^{\mathrm{v}}}{P+\left(\varepsilon_{\mathrm{m}}-1\right) P^{\mathrm{v}}}, \\
& q_{\mathrm{s}}^{*}=\frac{\varepsilon_{\mathrm{m}} P_{\mathrm{s}}^{\mathrm{v}}(\mathrm{SST})}{P+\left(\varepsilon_{\mathrm{m}}-1\right) P_{\mathrm{s}}^{\mathrm{v}}(\mathrm{SST})},
\end{aligned}
$$

where $P$ is the total pressure $(\mathrm{mB})$ and $\varepsilon_{\mathrm{m}}$ is the ratio between the mass-specific constants for dry air and for water vapor $\left(\varepsilon_{\mathrm{m}}=0.621\right) . P^{\mathrm{v}}$ is calculated from the relative humidity $(\mathrm{RH}$, in \%) and the partial pressure at saturation at the air temperature $T^{\mathrm{a}}\left(P_{\mathrm{s}}^{\mathrm{v}}\left(T^{\mathrm{a}}\right)\right.$, in $\left.\mathrm{mB}\right)$ :

$P^{\mathrm{v}}=\frac{\mathrm{RH}}{100} P_{\mathrm{s}}^{\mathrm{v}}\left(T^{\mathrm{a}}\right)$.

The partial pressures at saturation $P_{\mathrm{s}}^{\mathrm{v}}\left(T_{\mathrm{a}}\right)$ and $P_{\mathrm{s}}^{\mathrm{v}}(\mathrm{SST})$ are computed from the ClausiusClapeyron relationship.

The flux of sensible heat depends on the temperature difference between air and sea:

$F_{\mathrm{SE}}=\rho^{\mathrm{a}} C_{\mathrm{D}} W_{10}\left\{C_{\mathrm{p}}^{\mathrm{a}}\left(T^{\mathrm{a}}-\mathrm{SST}\right)\right\}$,

where $C_{\mathrm{p}}^{\mathrm{a}}$ is the mass-specific heat capacity of air at constant pressure (taken constant and equal to $1005 \mathrm{~J} \mathrm{~kg}^{-1} \mathrm{~K}^{-1}$ ).

The net flux of IR radiation to the ocean is given by:

$F_{\mathrm{IR}}=\sigma\left\{\varepsilon^{\mathrm{a}} T^{\mathrm{a} 4}-\varepsilon^{\mathrm{w}} \mathrm{SST}^{4}\right\}$.

$\sigma$ is the Stefan-Boltzmann constant $\left(5.67 \times 10^{-8} \mathrm{~W}\right.$ $\mathrm{m}^{-2} \mathrm{~K}^{-4}$ ). $\varepsilon^{\mathrm{a}}$ and $\varepsilon^{\mathrm{w}}$ (both dimensionless) are the emissivities of air and of the surface water, respectively; in this study, $\varepsilon^{\mathrm{a}}=0.80$ and $\varepsilon^{\mathrm{w}}=0.95$.

The zonal and meridional components of the wind stress at the surface ( $\tau_{x}$ and $\tau_{y}$, respectively, in $\mathrm{N} \mathrm{m}^{-2}$ ) are computed from the wind speed ( $\left.W_{10}\right)$ and the wind direction $(\theta$, zero for a northerly wind): $\tau_{x}=\rho^{\mathrm{a}} C_{\mathrm{D}} \mathrm{W}_{10}^{2} \sin (\theta-180)$,

$\tau_{y}=\rho^{\mathrm{a}} C_{\mathrm{D}} \mathrm{W}_{10}^{2} \cos (\theta-180)$.

Finally, the boundary condition for TKE at the sea surface $\left(\mathrm{TKE}_{\text {surf }}\right.$, in $\mathrm{m}^{2} \mathrm{~s}^{-2}$ ) is given by (from Blanke and Delécluse, 1993):

$\mathrm{TKE}_{\mathrm{surf}}=3.75 u^{* 2}$,

where $u^{*}\left(\mathrm{~m} \mathrm{~s}^{-1}\right)$ is the friction velocity in water. $u^{*}$ is calculated from the modulus of the wind stress:

$u^{* 2}=\frac{\sqrt{\tau_{x}^{2}+\tau_{y}^{2}}}{\rho^{\mathrm{w}}}$

\section{The surface exchange of $\mathrm{CO}_{2}$}

The piston velocity $v_{\mathrm{P}}$ (see eq. (7) in the text) is computed as a function of the wind speed recorded on Bermuda (Fig. 4A). For that purpose, the formula of Liss and Merlivat (1986) is used. In this formula, the Schmidt number for $\mathrm{CO}_{2}$ is calculated from the SST according to a polynomial and its value at $20^{\circ} \mathrm{C}$ is fixed to 660 (Wanninkhof, 1992). The values of $v_{\mathrm{P}}$ computed in this way are multiplied by 1.7 , in order to be in line with the global mean estimate of the ${ }^{14} \mathrm{CO}_{2}$ transfer velocity (Monfray, 1987; Watson, 1993). Finally, the solubility coefficient $\alpha\left(\mathrm{mgCm}^{-3} \mu \mathrm{atm}\right)$ is calculated from the surface temperature and salinity according to the formula of Weiss (1974) and the state equation in UNESCO (1983).

In a more rigorous treatment of the gas exchange (eq. (7) in the text), the partial pressures should be replaced by fugacities. Yet, at a total pressure of $1 \mathrm{~atm}$, the relative difference between the two quantities is less than $0.5 \%$ (UNESCO, 1991). This difference is thus neglected in this study. The values of $\mathrm{pCO}_{2}^{\mathrm{a}}$ are derived from $\mathrm{CO}_{2}$ mixing ratios in dry air measured for 1989 at the Bermuda East station from the NOAA flask network (WMO/GAW, 1992). Erroneous data and measurements in poorly mixed air masses influenced by local anthropogenic sources or strong local biospheric sources or sinks, are rejected according to the data selection detailed in the WMO/GAW report. In order to convert the mean of mixing ratio replicates into $\mathrm{pCO}_{2}^{\mathrm{a}}$, we use the total pressure, relative humidity, and air temperature recorded on St. David's Head. The values 
of $\mathrm{pCO}_{2}^{\mathrm{a}}$ calculated in this way are reported on Fig. 8 for the April-October period.

The partial pressure of $\mathrm{CO}_{2}$ in water $\left(\mathrm{pCO}_{2}^{\mathrm{w}}\right)$ is computed from the surface temperature $(T)$, salinity $(S)$, dissolved inorganic carbon (DIC), and total alkalinity (ALK). We have neglected the minute contributions of water alkalinity (Skirrow, 1975) and of phosphate and silicate alkalinities to the charge balance (surface $\left[\mathrm{PO}_{4}^{3-}\right]$ and $\left[\mathrm{H}_{3} \mathrm{SiO}_{4}^{-}\right]$are always $<1.5 \mu \mathrm{mol} \mathrm{kg}^{-1}$ at the BATS site, see Knap et al., 1991, 1992). Hence, this balance is only associated with carbonate and borate alkalinities and we have determined the speciation of DIC and the value of $\mathrm{pCO}_{2}^{\mathrm{w}}$ by solving a cubic equation for the proton activity (Millero, 1979). To this end, total boron is estimated from salinity using the proportionality constant in Culkin (1965), and different dissociation constants $(\mathrm{pK})$ of the $\mathrm{CO}_{2}$ system are used (see text): the pK's for carbonic acid proposed by Dickson and Millero (1987), Goyet and Poisson (1989), and Roy et al. (1993), and the pK for boric acid of Hansson (1972) (fitted to the equation of Millero, 1979) and Dickson (1990).

In order to estimate the relative importance of $T, S$, [DIC], [ALK] on $\mathrm{pCO}_{2}^{\mathrm{w}}$ at the BATS site, a linear approximation can be made (Keeling et al., 1993; Takahashi et al., 1993):

$$
\begin{aligned}
& \mathrm{d} \ln \mathrm{pCO}_{2}^{\mathrm{w}}=\left(\frac{\partial \ln \mathrm{pCO}}{\partial T}\right) \mathrm{d} T \\
&+\left(\frac{\partial \ln \mathrm{pCO}_{2}^{\mathrm{w}}}{\partial S}\right) \mathrm{d} S \\
&+\left(\frac{\partial \ln \mathrm{pCO}}{\partial[\mathrm{DIC}]}\right) \mathrm{d}[\mathrm{DIC}] \\
&+\left(\frac{\partial \ln \mathrm{pCO}}{\partial[\mathrm{ALK}]}\right) \mathrm{d}[\mathrm{ALK}]
\end{aligned}
$$

The partial derivatives $\partial \ln \mathrm{pCO}_{2}^{\mathrm{w}} / \partial x$ or $x / \mathrm{pCO}_{2}^{\mathrm{w}} \partial \mathrm{pCO}_{2}^{\mathrm{w}} / \partial x$ (where $x=T, S, \quad$ [DIC],
[ALK]) are estimated by computing $\mathrm{pCO}_{2}^{\mathrm{w}}$ versus $x$ in the range of surface variation of $x$ near Bermuda. The different dissociation constants reported above are used for that purpose. The slopes of the least squares lines $\ln \mathrm{pCO}_{2}^{\mathrm{w}}$ versus $T$, $\ln S, \ln [\mathrm{DIC}]$, and $\ln [\mathrm{ALK}]$ are hence determined (in each case, $n=21$, coeff. of determination $=0.999$, and STD error of est. $=1 \mu \mathrm{atm}$ ):

$\frac{1}{\mathrm{pCO}_{2}^{\mathrm{w}}} \frac{\partial \mathrm{pCO}_{2}^{\mathrm{w}}}{\partial T}=0.0365-0.0392^{\circ} \mathrm{C}^{-1}$,

$\frac{S}{\mathrm{pCO}_{2}^{\mathrm{w}}} \frac{\partial \mathrm{pCO}_{2}^{\mathrm{w}}}{\partial S}=0.85-0.96$,

$\frac{[\mathrm{DIC}]}{\mathrm{pCO}_{2}^{\mathrm{w}}} \frac{\partial \mathrm{pCO}_{2}^{\mathrm{w}}}{\partial[\mathrm{DIC}]} \approx 9.0$,

$\frac{[\mathrm{ALK}]}{\mathrm{pCO}_{2}^{\mathrm{w}}} \frac{\partial \mathrm{pCO}_{2}^{\mathrm{w}}}{\partial[\mathrm{ALK}]} \approx-8.4$.

These values are in agreement with global ranges reported by Takahashi et al. (1993) from earlier pK's (here, the ranges of variation are due to the use of different dissociation constants). From eqs. (8.12)-(8.15) and considering seasonal amplitudes of $8^{\circ} \mathrm{C}, 0.4$, and $30-40 \mu \mathrm{mol} \mathrm{kg}^{-1}$ at the BATS site, the seasonal cycle of $\mathrm{pCO}_{2}^{\mathrm{w}}$ seems primarily controlled by variations in temperature $\left(\Delta \mathrm{pCO}_{2}^{\mathrm{w}} / \mathrm{pCO}_{2}^{\mathrm{w}}=0.29-0.31\right)$, and to a lesser extent, by changes in [DIC] $\left(\triangle \mathrm{pCO}_{2}^{\mathrm{w}} / \mathrm{pCO}_{2}^{\mathrm{w}}=\right.$ 0.13-0.18) ( $[\mathrm{ALK}]$ is in general strongly correlated with $S$ in the M at the BATS site $\left(r^{2}=0.91\right.$; Bates et al., 1995). The effect of [ALK] changes on $\mathrm{pCO}_{2}^{\mathrm{w}}$ are thus largely compensated by [DIC] changes caused by evaporation/precipitation at the surface). Keeling (1993) came to the same conclusion from his data at station S. In this study, variations in salinity and alkalinity are therefore neglected. Their profiles are fixed to surface averages of 36.6 (see above) and $2930 \mu \mathrm{eq} \mathrm{kg}{ }^{-1}$, respectively (this [ALK] value is about the mean value of the 7 year time-series data at station $S$ ).

\section{REFERENCES}

Bates, N. R., Knap, A. H. and Michaels, A. F. 1992. Seasonal variability in dissolved inorganic carbon, alkalinity, and $\mathrm{pCO}_{2}$ in the northwestern Sargasso
Sea: U.S. JGOFS Bermuda Atlantic Time-series Station. EOS Trans. Am. Geophys. Union. 73, 43.

Bates, N. R., Michaels, A. F. and Knap, A. H. 1993. 
Seasonal variability of the oceanic $\mathrm{CO}_{2}$ system in the Sargasso Sea: US JGOFS Bermuda Atlantic Timeseries Study. Abstract, Third Scientific Meeting of The Oceanographic Society, April 13-16, 1993, Seattle, Washington.

Bates, N. R., Knap, A. H. and Michaels, A. F. 1994. Temporal and spatial variability of the inorganic carbon system in the Sargasso Sea, November 1988 to January 1994. EOS Trans. Am. Geophys. Union (suppl.) 75, no. 3 .

Bates, N. R. 1995. Investigation of the physical and biological controls of the oceanic $\mathrm{CO}_{2}$ system in the Sargasso Sea. PhD Dissertation, University of Southampton, UK.

Bates, N. R., Michaels, A. F. and Knap, A. H. 1995. Seasonal and interannual variability of the oceanic carbon dioxide system at the US JGOFS Bermuda Atlantic Time-series Study site. Deep Sea Res., in press.

Blanke, B. and Delécluse, P. 1993. Variability of the tropical Atlantic Ocean simulated by a General Circulation Model with two different mixed layer physics. J. Phys. Oceanogr. 23, 1363-1388.

Bougeault, P. and Lacarrère, P. 1989. Parametrization of orography-induced turbulence in a mesobeta-scale model. Month. Wea. Rev. 117, 1872-1890.

Broecker, W. S. and Peng, T.-H. 1982. Tracers in the sea. Eldigio Press, Lamont-Doherty Geological Observatory, Palisades, New York, $690 \mathrm{pp}$.

Carlson, C. A., Ducklow, H. W. and Michaels, A. F. 1994. Annual flux of dissolved organic carbon from the euphotic zone in the northwestern Sargasso Sea. Nature 371, 405-408.

Carpenter, E. J. 1983. Nitrogen fixation by marine Oscillatoria (Trichodesmium) in the world's oceans. In: Nitrogen in the marine environment (eds. E. J. Carpenter and D. G. Capone). Academic Press, New York, 65-103.

Copin-Montégut, C. 1988. A new formula for the effect of temperature on the partial pressure of $\mathrm{CO}_{2}$ in seawater. Mar. Chem. 25, 29-37.

Cornell, S., Rendell, A. and Jickells, T. 1995. Atmospheric inputs of dissolved organic nitrogen to the oceans. Nature 376, 243-246.

Culkin, F. 1965. The major constituents of sea water. In: Chemical oceanography (eds. J. P. Riley and G. Skirrow), vol. 1, ch. 4, 1st edition. London: Academic Press, 121-161.

Dickson, A. G. and Riley, J. P. 1978. The effects of analytical error on the evaluation of the components of the aquatic carbon-dioxide system. Mar. Chem. 6, 77-85.

Dickson, A. G. and Millero, F. J. 1987. A comparison of the equilibrium constants for the dissociation of carbonic acid in seawater media. Deep-Sea Res. 34, 1733-1743.

Dickson, A. G. 1990. Thermodynamics of the dissociation of boric acid in synthetic seawater from 273.15 to 318.15 K. Deep-Sea Res. 37, 755-766.

Duce, R. A. 1986. The impact of atmospheric nitrogen, phosphorous, and iron species on marine biological productivity. In: The role of air-sea exchange in geochemical cycling (ed. P. Buat-Ménard). D. Reidel Publishing Company, Hingham, Massachusetts, 497-529.

Duce, R. A. et al. 1991. The atmospheric input of trace species to the world ocean. Global Biogeochem. Cycles 5, 193-259.

Dugdale, R. C. and Goering, J. J. 1967. Uptake of new and regenerated forms of nitrogen in primary productivity. Limnol. Oceanogr. 12, 196-206.

Eppley, R. and Peterson, B. 1979. Particulate organic matter flux and planktonic new production in the deep ocean. Nature 282, 677-680.

Garçon, V. C., Thomas, F., Wong, C. S. and Minster, J.-F. 1992. Gaining insight into the seasonal variability of $\mathrm{CO}_{2}$ at Ocean Station $\mathrm{P}$ using an upper ocean model. Deep-Sea Res. 39, 921-938.

Gaspar, P., Grégoris, Y. and Lefèvre, J.-M. 1990. A simple eddy kinetic energy model for simulations of the oceanic vertical mixing: tests at Station Papa and Long-Term Upper Ocean Study site. J. Geophys. Res. 95, 16179-16193.

Goyet, C. and Poisson, A. 1989. New determination of carbonic acid dissociation constants in seawater as a function of temperature and salinity. Deep-Sea Res. 36, 1635-1654.

Goyet, C., Beauverger, C., Brunet, C. and Poisson, A. 1991. Distribution of carbon dioxide partial pressure in surface waters of the Southwest Indian Ocean. Tellus 43B, 1-11.

Goyet, C. and Hacker, S. D. 1992. Procedure for calibration of a coulometric system used for total inorganic carbon measurements of seawater. Mar. Chem. 38, 37-51.

Hansson, I. 1972. An analytical approach to the carbonate system in seawater. PhD Thesis, University of Göteborg, Sweden.

Ivanoff, A. 1977. Ocean absorption of solar energy. In: Modelling and prediction of the upper layers of the ocean (ed. E. B. Kraus). Pergamon, New York, 47-71.

Jenkins, W. J. and Goldman, J. C. 1985. Seasonal oxygen cycling and primary production in the Sargasso Sea. J. Mar. Res. 43, 465-491.

Karl, D. M., Letelier, R., Hebel, D. V., Bird, D. F. and Winn, C. D. 1992. Trichodesmium blooms and new nitrogen in the north Pacific gyre. In: Marine pelagic cyanobacteria: Trichodesmium and other diazotrophs (eds. E. J. Carpenter, D. G. Capone and J. G. Reuter). Kluwer Academic, Dordrecht, 219-237.

Keeling, C. D. 1993. Lecture 2: surface ocean $\mathrm{CO}_{2}$. In: The global carbon cycle (ed. M. Heimann). SpringerVerlag, Berlin Heidelberg, 413-429.

Keeling, R. F., Najjar, R. P., Bender, M. L. and Tans, P. P. 1993. What atmospheric oxygen measurements can tell us about the global carbon cycle. Global. Biogeochem. Cycles 7, 37-67.

Kirk, J. T. O. 1983. Light and photosynthesis in aquatic 
ecosystems. Cambridge University Press, Cambridge, $401 \mathrm{pp}$.

Knap, A. H., Michaels, A. F., Dow, R. L., Johnson, R. J., Gundersen, K., Knauer, G. A., Lohrenz, S. E., Asper, V. A., Tuel, M., Ducklow, H., Quinby, H. and Brewer, P. G. 1991. US Joint Global Ocean Flux Study. Bermuda Atlantic Time-Series Study. Data Report B-1A, BATS 1-BATS 12, October 1988-September 1989. US JGOFS Planning Office, Woods Hole, Massachusetts, $268 \mathrm{pp}$.

Knap, A. H., Michaels, A. F., Dow, R. L., Johnson, R. J., Gundersen, K., Sorensen, J. C., Close, A. R., Hammer, M., Knauer, G. A., Lohrenz, S. E,, Asper, V. A., Tuel, M., Ducklow, H., Quinby, H., Brewer, P. G. and Bidigare, R. 1992. US Joint Global Ocean Flux Study. Bermuda Atlantic Time-Series Study. Data Report B-2, BATS 13-BATS 24, October 1989September 1990. US JGOFS Planning Office, Woods Hole, Massachusetts, 345 pp.

Knap, A. H., Michaels, A. F., Dow, R. L., Johnson, R. J., Gundersen, K., Sorensen, J. C., Close, A. R., Howse, F. A., Hammer, M., Bates, N., Doyle, A. and Waterhouse, T. 1993. BATS Method Manual. US JGOFS Planning and Coordination Office, Woods Hole, Massachusetts, $108 \mathrm{pp}$.

Laws, E. A. 1991. Photosynthetic quotients, new production and net community production in the open ocean. Deep-Sea Res. 38, 143-167.

Liss, P. S. and Merlivat, L. 1986. Air-sea gas exchange rates: introduction and synthesis. In: The role of air-sea gas exchange in geochemical cycling (ed. P. BuatMénard). D. Reidel Publishing Company, Hingham, Massachusetts, 113-127.

Lohrenz, S. E., Knauer, G. A., Asper, V. L., Tuel, M., Michaels, A. F. and Knap, A. H. 1992. Seasonal variability in primary production and particle flux in the northwestern Sargasso Sea: US JGOFS Bermuda Atlantic Time-series Study. Deep-Sea Res. 39, 1373-1391.

Malone, T. C., Pike, S. E. and Conley, D. J. 1993. Transient variations in phytoplankton productivity at the JGOFS Bermuda time series station. Deep-Sea Res. 40, 903-924.

Martin, J. H., Knauer, G. A., Karl, D. M. and Broenkow, W. W. 1987. VERTEX: carbon cycling in the northeast Pacific. Deep-Sea Res. 34, 267-285.

Martin, J. H., Fitzwater, S. E., Gordon, R. M., Hunter, C. N. and Tanner, S. J. 1993. Iron, primary production and carbon-nitrogen flux studies during the JGOFS North Atlantic Bloom Experiment. Deep-Sea Res. 40, 115-134.

McCarthy, J. J. and Carpenter, E. J. 1983. Nitrogen cycling in near-surface waters of the open ocean. In: Nitrogen in the marine environment (eds. E. J. Carpenter and D. G. Capone). Academic Press, New York, 487-512.

Mellor, G. L. and Durbin, P. A. 1975. The structure and dynamics of the ocean surface mixed layer. J. Phys. Oceanogr. 5, 718-728.
Menzel, D. W. and Ryther, J. H. 1960. The annual cycle of primary production in the Sargasso Sea off Bermuda. Deep-Sea Res. 6, 351-367.

Michaels, A. F., Siegel, D. A., Johnson, R. J., Knap, A. H. and Galloway, J. N. 1993. Episodic inputs of atmospheric nitrogen to the Sargasso Sea: contributions to new production and phytoplankton blooms. Global Biogeochem. Cycles 7, 339-351.

Michaels, A. F., Knap, A. H., Dow, R. L., Gundersen, K., Johnson, R. J., Sorensen, J., Close, A., Knauer, G. A., Lohrenz, S. E., Asper, V. A., Tuel, M. and Bidigare, R. 1994a. Seasonal patterns of ocean biogeochemistry at the US JGOFS Bermuda Atlantic Time-series Study site. Deep-Sea Res. 41, 1013-1038.

Michaels, A. F., Bates, N. R., Buesseler, K. O., Carlson, C. A. and Knap, A. H. 1994b. Carbon-cycle imbalances in the Sargasso Sea. Nature 372, 537-540.

Millero, F. J. 1979. The thermodynamics of the carbonate system in seawater. Geochim. Cosmochim. Acta 43, 1651-1661.

Monfray, P. 1987. Echanges océan/atmosphère du gaz carbonique: variabilité avec l'état de la mer. PhD Dissertation, Université de Picardie, France.

Musgrave, D. L., Chou, J. and Jenkins, W. J. 1988. Application of a model of upper-ocean physics for studying seasonal cycles of oxygen. J. Geophys. Res. 93, 15679-15700.

Niiler, P. P. and Kraus, E. B. 1977. One-dimensional models of the upper ocean. In: Modelling and prediction of the upper layers of the ocean (ed. E. B. Kraus). Pergamon, New York, 143-172.

Olbers, D. J., Wenzel, M. and Wilebrand. 1985. The inference of North Atlantic circulation patterns from climatological hydrographic data. Rev. Geophys. 23, 313-356.

Paulson, C. A. and Simpson, J. J. 1977. Irradiance measurements in the upper ocean. J. Phys. Oceanogr. 7, 952-956.

Platt, T. and Harrison, W. G. 1985. Biogenic fluxes of carbon and oxygen in the ocean. Nature 318, 55-58.

Redfield, A. C., Ketchum, B. H. and Richards, F. A. 1963. The influence of organisms on the composition of seawater. In: The sea, vol. 2 (ed. M. N. Hill). Interscience, New York, 26-77.

Roman, M. R., Dam, H. G., Gauzens, A. L. and Napp, J. M. 1993. Zooplankton biomass and grazing at the JGOFS Sargasso Sea time series station. Deep-Sea Res. 40, 883-901.

Roy, R. N., Roy, L. N., Vogel, K. M., Porter-Moore, C., Pearson, T., Good, C. E., Millero, F. J. and Campbell, D. M. 1993. The dissociation constants of carbonic acid in seawater at salinities 5 to 45 and temperatures 0 to $45^{\circ}$ C. Mar. Chem. 44, 249-267.

Sambrotto, R. N., Savidge, G., Robinson, C., Boyd, P., Takahashi, T., Karl, D. M., Langdon, C., Chipman, D., Marra, J. and Codiposti, L. 1993. Elevated consumption of carbon relative to nitrogen in the surface ocean. Nature 363, 248-250.

Siegel, D. A., Michaels, A. F., Sorensen, J. C., O'Brien, 
M. C. and Hammer, M. A. 1995. Seasonal variability of light availability and utilization in the Sargasso Sea. J. Geophys. Res. 100, 8695-8713.

Skirrow, G. 1975. The dissolved gases-carbon dioxide. In: Chemical oceanography, vol. 2, 2nd edition (eds. J. P. Riley and G. Skirrow). Academic Press, 1-181.

Spitzer, W. S. and Jenkins, W. J. 1989. Rates of vertical mixing, gas exchange and new production: Estimates from seasonal gas cycles in the upper ocean near Bermuda. J. Mar. Res. 47, 169-196.

Takahashi, T., Olafsson, J., Goddard, J. G., Chipman, D. W. and Sutherland, S. C. 1993. Seasonal variation of $\mathrm{CO}_{2}$ and nutrients in the high-latitude surface oceans: a comparative study. Global Biogeochem. Cycles 7, 843-878.

Thomas, F., Garçon, V. and Minster, J.-F. 1990. Modelling the seasonal cycle of dissolved oxygen in the upper ocean at Ocean Weather Station P. Deep-Sea Res. 37, 463-491.

Thomas, F., Minster, J.-F., Gaspar, P. and Grégoris, Y. 1993. Comparing the behaviour of two ocean surface models in simulating dissolved $\mathrm{O}_{2}$ concentration at OWSP. Deep-Sea Res. 40, 395-408.

Toggweiler, J. R. 1993. Carbon overconsumption. Nature 363, 210-211.

Toggweiler, J. R. 1995. Vanishing in Bermuda. Nature 372, 505-506.

TTO, 1986. North Atlantic Study, 1 April-19 October 1981, Shipboard physical and chemical data report. Physical \& Chemical Oceanographic Data Facility, Scripps Institution of Oceanography, University of California, San Diego, 714 pp.

UNESCO, 1983. Algorithms for computation of fundamental properties of seawater. Endorsed by Unesco/SCOR/ICES/IAPSO Joint Panel on Oceanographic Tables and Standards and SCOR Working Group 51. UNESCO Tech. Pap. Mar. Sci. 44, 53 pp.

UNESCO, 1987. Thermodynamics of the carbon dioxide system in seawater. Report by the carbon dioxide subpanel of the joint panel on oceanographic tables and standards. UNESCO Tech. Pap. Mar. Sci. 60, $41 \mathrm{pp}$.

UNESCO, 1991. Reference materials for oceanic carbon dioxide measurements. Report of the sub-panel on standards for $\mathrm{CO}_{2}$ measurements of the Joint Panel on Oceanographic Tables and Standards, sponsored by SCOR/Unesco/ICES/IAPSO. UNESCO Tech. Pap. Mar. Sci. 60, 41 pp.

Wanninkhof, R. 1992. Relationship between wind speed and gas exchange over the ocean. J. Geophys. Res. 97, 7373-7382.

Watson, A. 1993. Air-sea exchange and carbon dioxide. In: The global carbon cycle (ed. M. Heimann). Springer-Verlag, Berlin, 397-411.

Weiss, R. F. 1970. The solubility of nitrogen, oxygen and argon in water and seawater. Deep-Sea Res. 17, 721-735.

Weiss, R. F. 1974. Carbon dioxide in water and seawater: the solubility of a non-ideal gas. Mar. Chem. 2 , 203-215.

Williams, P. J. leB. and Robertson, J. E. 1991. Overall planktonic oxygen and carbon dioxide metabolisms: the problem of reconciling observations and calculations of photosynthetic quotients. J. Plankton Res. 13 , $153-169$.

WMO/GAW, 1992. World Meteorological Organization Global Atmosphere Watch World Data Centre for Greenhouse Gases Data Report. Part A (Carbon dioxide), GAW data, Volume $I V$. Greenhouse gases and other atmospheric gases (eds. The Japan Meteorological Agency in cooperation with the World Meteorological Organization). Tokyo, $776 \mathrm{pp}$.

Worthington, L. V. 1976. On the North Atlantic circulation. The Johns Hopkins Oceanographic Studies, no. 6, Baltimore, Johns Hopkins University Press, $110 \mathrm{pp}$. 